\title{
Biomedical Magnesium Alloys: A Review of Material Properties, Surface Modifications and Potential as a Biodegradable Orthopaedic Implant
}

\author{
Gé rrard Eddy Jai Poine rn ${ }^{*}$, Sridevi Brundavanam, De re k Fawcett
}

Murdoch Applied Nanotechnology Research Group, Department of Physics, Energy Studies and Nanotechnology, School of En gin eering and Energy, Murdoch University, Murdoch, Western Australia, 6150, Australia

\begin{abstract}
Magnesium and magnesium based alloys are lightweight metallic materials that are extremely biocompatible and have similar mechanical properties to natural bone. These materials have the potential to function as an osteoconductive and biodegradable substitute in load bearing applications in the field of hard tissue engineering. However, the effects of corrosion and degradation in the physiological environ ment of the body has prevented their wide spread application to date. The aim of this review is to examine the properties, chemical stability, degradation in situ and methods of improving the corrosion resistance of magnesium and its alloys for potential application in the orthopaedic field. To be an effective implant, the surface and sub-surface properties of the material needs to be carefully selected so that the degradation kinetics of the implant can be efficiently controlled. Several surface modification techniques are presented and their effectiveness in reducing the corrosion rate and methods of controlling the degradation period are discussed. Ideally, balancing the gradual loss of material and mechanical strength during degradation, with the increasing strength and stability of the newly forming bone tissue is the ultimate goal. If this goal can be achieved, then orthopaedic implants manufactured from magnesium based alloys have the potential to deliver success ful clinical outcomes without the need for revision surgery.
\end{abstract}

Keywords Magnesium, Bio logical Corrosion, Biocompatibility, Alloys, Surface Modification

\section{Introduction}

The skeletal system of the human body is a complex three-dimensional structure that is important for two main reasons. The first arises from the need to structurally support the many body organs and other related tissues. The second is the attachment of the numerous muscle groups that are needed for body movement and loco motion. The skeleton is constructed of two types of tissue, the first is a hard tissue called bone and the second is a softer tissue composed of cartilag inous materials. The adult hu man skeleton consists of 206 bones[1]; some provide protection to the internal organs, while others perform specialized functions such as transmitting sound vibrations in the inner ear. The bone matrix also provides a natural reservoir for cells and mineral ions that play an important role in maintaining the biochemical balance within the body. For example, calcium is an important element involved in muscular action and nerve conduction and its level in the body is closely monitored and regulated by a process called homeostasis[2].

*Corresponding author:

g.poinern@murdoch.edu.au (Gérrard Eddy Jai Poinern)

Published online at http://journal.sapub.org/ajbe

Copyright (C) 2012 Scientific \& Academic Publishing. All Rights Reserved
Bone is a natural two phase organic-inorganic ceramic composite consisting of collagen fibrils with an embedded inorganic nano-crystalline component. The primary organic phase of the bone matrix is Type I collagen, which is secreted by osteoblast cells to form self-assembled fibrils [3, 4]. The fibrils are bundled together and orientate themselves parallel to the load-bearing axis of the bone. The fibrils are typically $300 \mathrm{~nm}$ long, develop a $67 \mathrm{~nm}$ periodic pattern in which a 40 nm gap or hole is formed between the ends of the fibrils and the remaining $27 \mathrm{~nm}$ overlaps the bundle behind[5]. This pattern creates discrete and discontinuous sites for the deposition of plate-like nanometre sized hydroxyapatite (HAP) crystals, which forms the second phase of the bone matrix. HAP is a mineral predominantly composed of calcium phosphate which has the general chemical formula of $\left[\mathrm{Ca}_{10}(\mathrm{OH})_{2}\left(\mathrm{PO}_{4}\right)_{6}\right]$. It is the main inorganic component of bone and teeth, accounting for up to $65 \%$ by weight of cortical bone and in the case of teeth it accounts for $97 \%$ by weight of dental enamel in mammalian hard tissue[6]. The discontinuous discrete sites limit the growth of the HAP crystals and force the crystals to grow with a specific crystalline orientation which is parallel to the load-bearing axis of the bone and collagen fibrils. The crystal plates typically have a length of $50 \mathrm{~nm}$, a width of around $25 \mathrm{~nm}$ and on average a thickness of $3 \mathrm{~nm}[7-10]$. The HAP also has 
trace amounts of potassium, manganese, sodium, chloride, hydrogen phosphate, citrate and carbonate[11]. The final component of the bone matrix consists of the non-collagen organic proteins such as the phosphor-protein group which are believed to regulate the formation of the inorganic crystal phase by influencing the size, orientation and the depositional environment within the spaces between the collagen fibrils. The phosphor-protein group is also believed to be the source of calcium and phosphate ions used in the formation of the mineral phase[12].

The organic phase gives bone its flexibility, while the inorganic phase provides bone with its structural rig idity $[13$, 14]. The incorporation of organic and inorganic phases in the matrix gives bone its unique mechanical properties such as toughness, strength, and stiffness. It is the combination of these properties that give bone and the skeletal system in general, its remarkable ability to withstand the various mechanical and structural loads encountered during normal and intense physical activity[15]. However, not all bone tissue in the body has the same properties and this is characterized by the presence of two types of bone. The first type consists of a hard outer layer of compact (cortical) tissue, while the second type forms the less dense and spongy (trabecular) tissue which fills the interior of the bone. This spongy interior contains marrow and the many blood vessels that supply nutrients and remove waste products from the bone tissues. Both the cortical bone and the trabecular bone are composed of the same organic and inorganic phases discussed above, but they differ in the a mount of each phase present. The two bone types also differ in their respective porosities and in their structural arrangement. The amount of cortical and trabecular tissue found in bone is dependent on the external load being applied and the frequency of the load[16]. Despite its remarkable mechanical and structural properties bone can fracture from three main causes: 1) a fracture caused by sudden injury; 2) Fatigue or stress fractures resulting from repeated cyclic loads; and 3) Pathological fractures resulting from bone infections and tumours[17]. The surgical implantation of artificial biomaterials of specific size and shape is an effective solution in restoring the load bearing capacity and functionality of damaged bone tissue. The design and selection of bio materials is highly dependent on the specific medical application. Therefore, it is imperative that new biomaterials being developed for load bearing orthopaedic implant applications should have excellent bioco mpatibility, comparable strength to natural bone, and produce no cytotoxicity effects $[18,19]$.

Metallic b io materia ls have been used since the early 1900 s to replace damaged or diseased hard tissues. And as early as 1907, a magnesium alloy was used by Lambotte, to secure a bone fracture in the lower leg[20,21]. Metallic implants are generally used in load bearing applications where their high mechanical strength and fracture toughness make's them superior to ceramics, polymeric materials and polymer / ceramic composites. Metallic implant materials currently used include stainless steel, cobalt-chrome alloys and titanium and its alloys. At present there are two major problems associated with using the metallic implants. The first involves the mismatch between the mechanical properties of the metallic alloy and the surrounding natural bone tissue. The elastic modulus of both stainless steel and cobalt-chrome alloys is around ten times greater than that of bone, while a titaniu m alloy such as Ti- $6 \mathrm{Al}-4 \mathrm{~V}$ is around five times greater[22]. Bone tissue is constantly undergoing remodelling and modification in response to imposed stresses produced by normal everyday activities. The mechanical mis match between bone and different metallic implant materials results in a clin ical phenomenon known as stress shielding. The stress-shielding phenomenon occurs when the implant carries the bulk of the load and the surrounding bone tissue experiences a reduced loading stress. The reduced loading stress experience by the surrounding bone tis sue ultimately leads to bone resorption[23, 24]. The second problem stems from mechanical wear and corrosion of the implant and results in the release of toxic metallic ions such as chromium, cobalt and nickel into the body. These harmful metallic ions solicit an inflammatory response from the body's immune system and the surrounding tissues which reduces the biocompatibility of the implant $[25,26$, and 27]. This is in total contrast to the corrosion products of magnesium $(\mathrm{Mg})$ which can be considered physiologically beneficial, with the adult body storing around $30 \mathrm{~g}$ of $\mathrm{Mg}$ in both muscle and bone tissue[28]. The importance of Mg to the body stems from the fact it is bivalent ion which is used to form apatite in the bone matrix and is also used in a number of metabolic processes within the body[29]. And recently, Robinson et al. reported the novel antibacterial properties of $\mathrm{Mg}$ metal against Escherichia coli, Pseudomonas aeruginosa and Staphylococcus aureus[30].

$\mathrm{Mg}$ is a lightweight, silvery-white metal that is relatively weak in its pure state and is generally used as an alloy in engineering applications. The density of $\mathrm{Mg}$ and its alloys are around $1.74 \mathrm{~g} / \mathrm{cm}^{3}$ at $20^{\circ} \mathrm{C}$, which is 1.6 and 4.5 times less dense than aluminium and steel, respectively[31]. Interestingly, the density of $\mathrm{Mg}$ is slightly less than natural bone which ranges from 1.8 to $2.1 \mathrm{~g} / \mathrm{cm}^{3}$, while the elastic modulus of pure $\mathrm{Mg}$ is $45 \mathrm{GPa}$ and human bone varies between 40 and $57 \mathrm{GPa}[32,33$ and 34]. Because of this close similarity in the respective elastic moduli, using $\mathrm{Mg}$ in hard tissue engineering applications would greatly reduce the possibility of stress shielding and prevent bone resorption. Thus, Mg with its similar mechanical properties to natural bone, combined with its biocompatibility, makes it a promising material for the development of biodegradable orthopaedic implants [33,35].

Poly meric materials have also been used in a number of tissue engineering applications since they have many attractive properties such as being lightweight, ductile in nature, biocompatible and biodegradable. Polymers are materials with large molecules composed of small repeating structural units called monomers. The mono mers are usually attached by covalent chemical bonds, with cross-linking taking place along the length of the molecule. It is the 
amount of cross-linking that gives the polymer its physiochemical properties. Many polymeric materials have been investigated since the body's natural processes can easily handle the by-products resulting from their degradation, with the by-products being easily excreted in the urine. Natural poly mers such as polysaccharides [36-40], chitosan[41-46], hyaluronic based derivatives [47-50] and protein based materials such as fibrin gel[51, 52] and collagen[53-56], have all produced favourable outcomes in a number of tissue engineering applications.

Similar studies using synthetic biopolymers composed of simple high purity constituent monomers, fabricated under controllable formation conditions have produced a variety of tissue scaffolds and implants with tuneable and predictable physio-mechanical properties. These biopolymers also have low toxicity reactions with the body and their degradation rate can be easily controlled. Examples of synthetic biodegradable polymers include Poly (lactic acid), PLA[57-62], Poly (L-lactic acid), PLLA [63-66], Poly (lactic-co-glycolic acid), PLGA[67-70], Poly-caprolactone PCL[71-74] and Poly (glycolic acid), PGA [75-78]. These biopolymers are generally poly- $\alpha$-hydrox esters that de-esterifies in the body as the polymer degrades to simple metabolites[79]. Currently available biodegradable sutures in clinical use are made from PLA and PGA. These synthetic biopolymers can also be made into different shapes and structures, such as pellets, rods, disks, films, and fibres as required for the specific application. Some of these applications include biodegradable sutures, bone and dental cements, bone grafting materials, plates, screws, pins, fixation devices and low load bearing applications in orthopaedics[80, 81]. However, even with their many attractive properties, biopolymers have low mechanical strength when compared to ceramics and metals, which has resulted in thembeing used in soft tissue reconstruction and low-load bearing applications. The major advantage that $\mathrm{Mg}$ and its alloys have over biopolymers is its superior mechanical strength, which is typically double that of biopolymers.

Ceramics are non-metallic, inorganic materials that are used in hard tissue engineering applications where they are collectively termed bioceramics. The important properties of bioceramics that make them highly desirable for biomedical applications are: 1) they are physically strong; 2) they are both chemically and thermally stable; 3 ) they exhibit good wear resistance, and 4) they are durable in the body environment[82]. In addition, they are readily available, can be shaped to suit the application, they are biocompatible, hemocompatible, nontoxic, non-immunogenic and can be easily sterilised[83]. But unlike $\mathrm{Mg}$ and its alloys, bioceramics such as HAP, tend to be brittle, have low fracture toughness and are not as resilient. However, some bioceramics have found application in hip jo ints, coatings on implants, maxillofacial reconstruction, bone tissue engineering and drug delivery devices[81, 84-86].
A composite material consists of two or more distinct parts or phases[85]. The major advantage of using a composite biomaterial stems from the fact a single-phase material may not have all the required properties for a particular application[86]. However, by combining one or more phases with differing physical and chemical properties it is possible to create a composite material with superior properties to those of the individual components. A good example of a natural composite is bone, which is a composed of Type 1 collagen and HAP. A typical man made example of a biomedical composite is a bioactive coating of HAP or a bioactive glass deposited on to the surface of a titanium implant to promote bone attachment[87]. Composites, such as a 2-phase HAP-polymer mixture have also been developed to create a biomaterial with similar properties to natural bone for hard tissue engineering applications [88]. Unfortunately, as mentioned above, biopolymers biodegrade with time and as a result, the load bearing capacity and fracture toughness of the implant will decline with time.

When comparing the properties of $\mathrm{Mg}$ and its alloys with metals, polymers, ceramics and composites it can be shown that $\mathrm{Mg}$ and its alloys have many properties that are comparable, if not superior, see Table 1 . However, despite its many advantages, $\mathrm{Mg}$ has the disadvantage of having a high corrosion rate in the body. And as a result, medical application of $\mathrm{Mg}$ based implants has been severely limited due to the electrolytic aqueous environment of the chloride rich body fluid ( $\mathrm{pH}$ ranges between 7.4 and 7.6). Furthermore, there are two serious consequences of the rapid corrosion rate of $\mathrm{Mg}$ imp lants. The first is the rap id evolution of subcutaneous hydrogen gas bubbles which are produced at a rate too high for the surrounding tis sues to handle[89, 90]. These bubbles usually appear within the first week after surgery and can be easily treated by drawing off the gas using a subcutaneous needle[91]. The second consequence of the high corrosion rate is the loss of mechanical integrity of the Mg implant being used in the load bearing application. The rapid decrease in mechanical properties resulting from exposure to the body fluid environment means that the implant is unable to provide the necessary support for the healing bone tissue. Generally, the implant would be expected to maintain its mechanical integrity between 12 to 18 weeks while the healing process takes place and then slowly degrade while natural bone tissues replace the implant[92].

This article reviews the biological performance, mechanical properties and potential application of biodegradable $\mathrm{Mg}$ based alloys for orthopaedic implants. The major disadvantage of using $\mathrm{Mg}$ in many engineering applications is its low corrosion resistance, especially in electrolytic, aqueous environments where it rapidly degrades. To slow the degradation rate in situ, factors influencing the corrosion rate such as alloying elements, surface modification and surface treatments are examined and discussed in the following sections. 
Table 1. Some mechanical properties of selected materials

\begin{tabular}{|c|c|c|c|c|}
\hline Tissue/Material & $\begin{array}{l}\text { Den sity } \\
\left(\mathrm{g} \mathrm{cm}^{-3}\right)\end{array}$ & $\begin{array}{l}\text { Compressive } \\
\text { Strength } \\
(\mathrm{MPa}) \\
\end{array}$ & $\begin{array}{c}\text { Tensile } \\
\text { Strength } \\
\text { (MPa) }\end{array}$ & $\begin{array}{c}\text { Elastic } \\
\text { Modulus } \\
\text { (GPa) } \\
\end{array}$ \\
\hline $\begin{array}{l}\text { Natural Materials } \\
\text { Arterial wall } \\
\text { Collagen } \\
\text { Collagen(Rat tail tendon) } \\
\text { Cancellous bone } \\
\text { Cortical bone }\end{array}$ & $\begin{array}{c}- \\
- \\
- \\
1.0-1.4 \\
1.8-2.0\end{array}$ & $\begin{array}{c}- \\
- \\
- \\
1.5-9.3 \\
160 \text { Trans. } \\
240 \text { Long. }\end{array}$ & $\begin{array}{c}0.50-1.72 \\
60 \\
- \\
1.5-38 \\
35 \text { Trans. } \\
283 \text { Long. }\end{array}$ & $\begin{array}{c}0.001 \\
1.0 \\
3.75-11.5 \\
0.01-1.57 \\
5-23\end{array}$ \\
\hline $\begin{array}{l}\text { Magnesium Alloys } \\
\text { Pure magnesium } \\
\text { AZ31 (Extruded) } \\
\text { AZ91D (Die cast) }\end{array}$ & $\begin{array}{l}1.74 \\
1.78 \\
1.81\end{array}$ & $\begin{array}{c}20-115 \\
83-97 \\
160\end{array}$ & $\begin{array}{c}90-190 \\
241-260 \\
230\end{array}$ & $\begin{array}{l}45 \\
45 \\
45\end{array}$ \\
\hline $\begin{array}{l}\text { Other metal alloys } \\
\text { Cobalt-Chrome Alloys } \\
\text { Stainless Steel } \\
\text { Titanium Alloys }\end{array}$ & $\begin{array}{l}7.8 \\
7.9 \\
4.4\end{array}$ & $\begin{array}{l}- \\
- \\
-\end{array}$ & $\begin{array}{l}450-960 \\
480-620 \\
550-985\end{array}$ & $\begin{array}{l}195-230 \\
193-200 \\
100-125\end{array}$ \\
\hline $\begin{array}{l}\text { Ceramics } \\
\text { Synthet ic- Hydroxyapat ite } \\
\text { Alumina Ceramics } \\
\left(\mathrm{Al}_{2} \mathrm{O}_{3} 80 \%-99 \%\right)\end{array}$ & $\begin{array}{l}3.05-3.15 \\
3.30-3.99\end{array}$ & $\begin{array}{c}100-900 \\
2000-4000\end{array}$ & $\begin{array}{c}40-200 \\
- \\
\end{array}$ & $\begin{array}{l}70-120 \\
260-410\end{array}$ \\
\hline $\begin{array}{l}\text { Polymers } \\
\text { Polymethylmethacrylate } \\
\text { (PMMA) } \\
\text { Polyethylene- terephthalate } \\
\text { (PET) }\end{array}$ & $\begin{array}{l}1.12-1.20 \\
1.31-1.38\end{array}$ & $\begin{array}{c}45-107 \\
65-90\end{array}$ & $\begin{array}{l}38-80 \\
42-80\end{array}$ & $\begin{array}{l}1.8-3.3 \\
2.2-3.5\end{array}$ \\
\hline
\end{tabular}

Note: Table compiled from references[122, 126, 213, 218, 219, 220 and 221]

\section{Biological Corrosion of Magnesium}

\subsection{Corrosion Mechanism}

When unprotected chemically pure magnesium is exposed to humid atmospheric air it develops a thick dull gray amorphous layer composed of magnesium hydroxide $[\mathrm{Mg}$ $(\mathrm{OH})_{2}$ ]. The oxidation rate of this protective oxide layer is typically around $0.01 \mathrm{~mm} / \mathrm{yr}$, while the oxidation rate in salt water is around $0.30 \mathrm{~mm} / \mathrm{yr}[93]$. In magnesium alloys, controlling the alloying chemistry and the overall microstructure of the alloy can significantly reduce the corrosion rate.

Table 2. Corrosion rates for some magnesium alloys immersion in various media

\begin{tabular}{|c|c|c|c|}
\hline \multirow{2}{*}{ Material } & \multicolumn{2}{|c|}{$\begin{array}{c}\text { In vitro corrosion rate } \\
\left(\mathbf{m g . c m}^{-2} \cdot \mathbf{h}^{-1}\right)\end{array}$} & \multirow{2}{*}{$\begin{array}{c}\text { In vivo corrosion } \\
\text { rate } \\
\left.\text { (mg.mm }^{-2} \cdot \mathbf{y r}^{-1}\right)\end{array}$} \\
\cline { 2 - 3 } & $\begin{array}{c}\text { Hanks } \\
\text { Solu tion }\end{array}$ & $\begin{array}{c}\text { Simulated } \\
\text { Body } \\
\text { Fluid }\end{array}$ & - \\
\hline $\begin{array}{c}\text { Pure Mg } \\
(99.95 \%)\end{array}$ & 0.011 & 0.038 & 1.17 \\
\hline AZ31 & 0.0065 & - & 1.38 \\
\hline AZ91 & 0.0028 & - & 0.39 \\
\hline LAE442 & - & - & 1.56 \\
\hline WE43 & - & 0.085 & \\
\hline
\end{tabular}

Note: Table compiled from references[92, 96, 126, 213, 214 and 215]

For orthopaedic applications pure magnesium finds the human body a highly aggressive corrosive environment, see Table 2. The body fluids are composed of water, dis solved oxygen, proteins and electrolytic ions such as chloride and hydroxide. In this environment, magnesium with a negative electrochemical potential of $-2.37 \mathrm{~V}$, is very susceptible to corrosion and results in free ions migrating from the metal surface into the surrounding fluid environment.

These ions can form chemical species, such as metal oxides, hydroxides, chlorides and other compounds. In thermodynamic terms, with the assumption that there is no barrier to oxidation of the metal surface, the reaction would be very rapid, evolving hydrogen gas and consuming the metal substrate surface. But in reality the electrochemical reaction results in the migration of ions from the metal surface into solution, which forms species that result in the formation of an oxide layer that adheres to the metal surface. The $\mathrm{Mg}(\mathrm{OH})_{2}$ layer formed on the metal surface is slightly soluble and reacts with chorine ions to form highly soluble magnesium chloride and hydrogen gas [94, 95]. When the oxide layer fully covers and seals the metal surface, it forms a kinetic barrier or passive layer that physically limits or prevents further migration of ionic species across the metal oxide solution interface.

The corrosion of $\mathrm{Mg}$ in an aqueous physiological environment can be expressed in the following equations. The primary anodic reaction is expressed by the partial reaction presented in equation (1), at the same time the reduction of protons is expressed by the partial reaction occurring at the cathode (2). 


$$
\begin{gathered}
\text { Anodic reaction: } \mathrm{Mg} \rightarrow \mathrm{Mg}^{2-}+2 \mathrm{e}^{-} \\
\text {Cathodic reaction: } 2 \mathrm{H}_{2} \mathrm{O}+2 \mathrm{e}^{-} \rightarrow 2 \mathrm{OH}^{-}+\mathrm{H}_{2}
\end{gathered}
$$

Another undesirable cons equence of the corrosion process in $\mathrm{Mg}$ and its alloys is the formation of hydrogen gas. The rapid formation of hydrogen gas resulting from the rich chorine environment produces subcutaneous gas bubbles, which generally appear within the first week after surgery and then disappear after 2 to 3 weeks [92]. During the initial gas formation a subcutaneous needle can be used to draw off the gas. In 2007, Song postulated that a hydrogen evolution rate of $0.01 \mathrm{ml} / \mathrm{cm}^{2} /$ day can be tolerated by the human body and does not constitute a serious threat[96].

If the $\mathrm{Mg}$ corrosion rate can be regulated so that the hydrogen evolution rate is below this value, then the implant will not create a gas threat. The reactions of solid $\mathrm{Mg}$ and the $\mathrm{Mg}(\mathrm{OH})_{2}$ layer with chorine ions in the aqueous environment are presented in equations (3) and (4).

Solid Mg:

$$
\begin{aligned}
& \mathrm{Mg}(\mathrm{s}) \\
& \mathrm{Mg}(\mathrm{OH})_{2} \text { layer: } \\
& \mathrm{Mg}(\mathrm{OH})_{2(\mathrm{~s})}^{-}+2 \mathrm{CL}_{(\mathrm{aq})}^{-} \rightarrow \mathrm{MgCl}_{2}+2 \mathrm{e}^{-}
\end{aligned}
$$

The general reaction of the corrosion process is presented in equation (5).

$$
\mathrm{Mg}(\mathrm{s})+2 \mathrm{H}_{2} \mathrm{O}_{(1)} \rightarrow \mathrm{Mg}(\mathrm{OH})_{2(\mathrm{~s})}+\mathrm{H}_{2}(\mathrm{~g})
$$

Corrosion in the aqueous environment of the body is not as straight forward as corrosion in the industrial environment. This is due to the corrosion rate being influenced by a variety of other factors such as: 1) the $\mathrm{pH}$ of body fluids; 2) variations in the $\mathrm{pH}$ value; 3 ) concentration of ions; 4) the presence of proteins and protein adsorption on the orthopaedic implant; and 5) the influence of the surrounding tis sues [97, 98 and 99].

\subsection{Types of Biological Corrosion}

An important property of the oxide layer is its ability to remain fixed to the metal surface during a variety of mechanical loading situations. If the oxide layer ruptures during mechanical loading it will expose the pure $\mathrm{Mg}$ substrate to body fluids which will result in further corrosion. The clinical repercussion of the corrosion process is the loss of mechanicalstrength and the ultimate failure of the imp lant. Typical forms of $\mathrm{Mg}$ corrosion encountered within the body environment are discussed in the following sections.

\subsubsection{Galvanic Corrosion}

Galvanic corrosion takes place between two dissimilar metals, each with a different electrochemical potential, when they are in contact in the presence of an electrolyte which provides a pathway for the transfer of electrons. The less noble metal becomes anodic, corrodes and produces a build up of corrosion by-products around the contact site. For example, if gold screws are used to attach an $\mathrm{Mg}$ plate to bone during reconstructive procedure, the resulting electrolytic effect of the body fluids (serum or interstitial fluid) would preferentially attack the $\mathrm{Mg}$ plate; see Figure $1[100]$. Therefore, it would be good design practice to use metals with similar electrochemical properties when designing implant devices. For example, the fixation screws used to attach an $\mathrm{Mg}$ plate during a bone reconstruction procedure should be made of a titanium (Ti) alloy, since Ti is the closest metal to $\mathrm{Mg}$ in the electrochemical series. $\mathrm{Mg}$ is the most reactive metal in the electrochemical series and will always be the anode in any corrosion reaction[101]. Therefore, selection of Ti alloy fixation screws to secure the $\mathrm{Mg}$ plate ensures the lowest possible corrosion rate. Galvanic corrosion can also result from the presence of inter-metallic alloying elements or impurities present in the Mg matrix, see Figure 2.

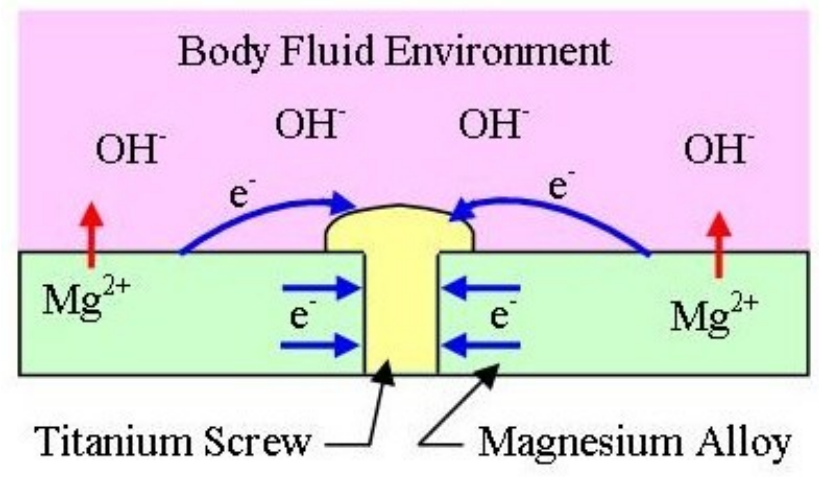

Figure 1. Galvanic corrosion between dissimilar metals

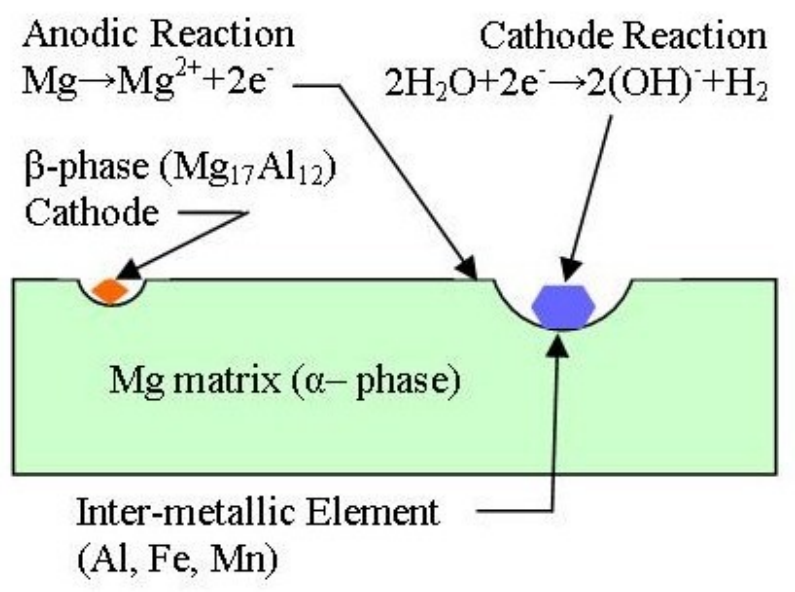

Figure 2. Galvanic corrosion resulting from int er-metallic elements

\subsubsection{Granular Corrosion}

In many metal alloys, inter-granular corrosion can occur from the presence of impurities and inclusions which are deposited in the gra in boundary regions during solidification. Following solidification, numerous galvanic reactions takes place between the metal matrix and the various impurities and inclusions. The ensuing corrosion rate at the various grain boundary regions exceeds that of the grains and results in an accelerated corrosion rate of the metal matrix. However, in the case of $\mathrm{Mg}$ alloys, inter-granular corrosion does not occur since the grains tend to be anodic, while their boundaries are cathodic in nature compared to the interior of the grains. The resulting grain boundary corrosion undercuts nearby grains which subsequently fall out of the matrix[102]. 


\subsubsection{Pitt ing Corrosion}

Pitting corrosion of $\mathrm{Mg}$ results from the rapid corrosion of small-localized areas which damage the protective surface oxide layer; see Figure 3. This form of corrosion is more serious than other forms of corrosion since the surface pits are difficult to see due to the presence of corrosion products. The pits are small, highly corrosive and continue to grow downwards, perforating the metal matrix[103]. After initial nucleation at the surface, the presence of impurities in the $\mathrm{Mg}$ alloy microstructure often as $\mathrm{sis}$ ts in further corrosion due to the galvanic differences in the materials[104, 105]. The environment within the pit is very aggressive, with chlorides species from the body fluids and $\mathrm{Mg}^{+}$ions from anodic dis solution greatly aggravating the situation. In addition, the mouth of the pit is s mall and prevents any dilution of the pit contents, which adds to the accelerating autocatalytic growth of the pit. During this process, electrons flowing from the pit make the surface surrounding the pit entrance become cathode-protected and the protective oxide layer is further weakened. Once pitting starts, an $\mathrm{Mg}$ component can be totally penetrated within a relatively short period of time and in the case of a biomed ical imp lant, its load bearing capacity would be greatly reduced to the point of failure. Another problem associated with pitting arises from localised increase in stress produced by the pit, which has the potential to form cracks[106]. The formation of stress corrosion cracking and metal fatigue cracks in the pits can lead to failure of the imp lant during normal loading conditions.

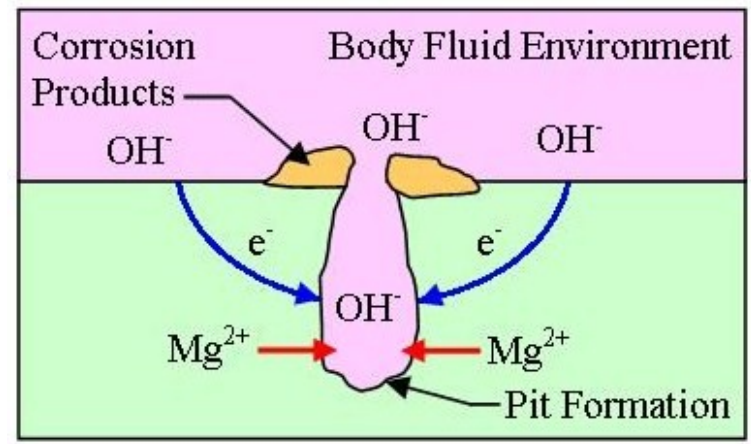

Figure 3. Pitting corrosion site at the surface of a magnesium component

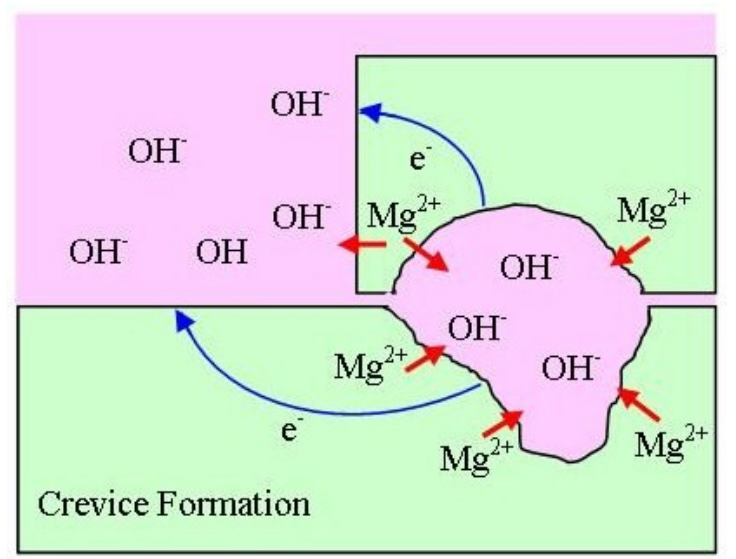

Figure 4. Crevice corrosion occurring between magnesium components in a body fluid environment

\subsubsection{Crevice Corrosion}

Crevice corrosion is local contact corrosion that occurs between metal and metal/non metal components. For example, if a magnesium plate is to be fixed in location by a set of screws with a small gap between the screw head and plate. The gap must have suffic ient width to allow the flow of the body fluids through the gap and prevent any stagnant flow, see Figure 4. The stagnant flow results in the build up of $\mathrm{Mg}^{+}$ions, with an $\mathrm{Mg}^{+}$ion concentration gradient soon set up between the entrance and the dead end of gap. The subsequent corrosion cell then starts to attack the metal components of the implant[107].

\subsubsection{Fretting Corrosion}

Fretting corrosion is the result of damage produced by metal components in direct physical contact with each other in the presence of small vibratory surface motions. The micro-motions are produced by normal every day activities experienced by the human body which result in mechanical wear and metallic debris between the surfaces of metal components making up the biomedical imp lant[108]. During daily activity, the mic ro-motions remove the passive surface layer of the metallic components in direct contact, exposing fresh metal underneath. Then both the fresh metal surfaces and the metallic surface debris undergo oxidation. The surface debris has a further detrimental effect by acting as an abrasive agent during subsequent micro-motions. The corrosion rate is dependent on the applied load, the resulting fretting motion, the microstructure of the metal or metal alloys used in the implant and solution chemistry in the region around the fretting zone[109, 110]. During the corrosion process metallic ions are produced which can form a wide range of organic-metallic complexes and some metallic implants can release toxic metallic ions such as chromium, cobalt and nickel. These harmful metallic ions significantly reduce the biocompatibility of the implant and solicit a major inflammatory response from the body's immune system[25, 26, and 27]. In the case of magnesium, metallic ions released during fretting, can be considered physiologically beneficial since these ions can be consumed or absorbed by the surrounding tissues, or be dissolved and readily excreted through the kidneys. Fretting corrosion is common in load bearing surfaces and is also capable initiating fatigue cracks in the fretting zone. Once formed the crack can propagate into the bulk of the metal matrix and can lead to the failure of the imp lant.

\subsubsection{Erosion Corrosion}

Erosion corrosion occurs from the wearing away of the metal surface or passive layer by the impact of wear debris in the body environment surrounding the implant. The metallic debris impacts on the surface of the implant, transferring energy into the region of the collision and plastically deforming the surface. During the deformation process the surface becomes work harden to the point where the next impact exceeds the strain required for surface fracturing, 
pitting or chip formation. With the passage of time, the numerous impacts result in material loss from the metal surface[111]. For example, a femoral head of a Cobalt-Chromium implant will have numerous scratches after 17 years of implantation in a patient[112]. All bio-metals used in implants inevitably corrode at some fin ite rate when immersed in the complex electrolytic environment of the body; even Ti alloys with the lowest corrosion rate produce corrosion debris. The debris can significantly influence the wear behaviour and erosion resistant properties of the implant. However, the effects of erosion may not be noticed until there is a significant loss of metal which ultimately leads to the clinical failure of the implant.

\subsubsection{Stress Corrosion}

When an electrochemical potential is formed between stressed and unstressed regions of a metal implant under load, there is an increase in the chemical activity of the metal. This stress initiated corrosion mechanism effectively increases the corrosion rate, usually by two to three times above the normal uniform rate. This usually results in the formation of s mall cracks that concentrate stress within the loaded implant, a mechanism know as stress corrosion cracking (SCC). Mg SCC can occur in any load stressed implant immersed in the dilute chloride environment of the body fluids. SCC initiated cracks grow rapidly and extend between the grains throughout the metal matrix[113, 114]. The progress of SCC is also influenced by the strain rate resulting from the implant loading cycles and the presence of hydrogen gas produced by the corrosion process $[115,116]$. Current research suggests that chloride ions produce pitting in the protective surface layer, which ultimately leads to a break down in the layer exposing the underlining $\mathrm{Mg}$ matrix to the electrolytic fluids of the body environment. The resulting hydrogen diffuses into the stressed zone of the metal matrix ahead of the crack tip and allows the SCC crack to advance through the zone[117-119]. Fracture and failure of the imp lant will occur when the SCC is below the normal operating stress of the implant.

\subsubsection{Corrosion Fatigue}

Corrosion fatigue is the result of a material being exposed to the combined effects of a cycling load and a corrosive environment[120]. In general, metal fatigue is the damage caused by the repeated loading and unloading of a metal component. The cyclic stress initiates the formation of microscopic cracks on the metal surface and also damages the protective passive layer. If there are any surface imperfections such as pores or pitting from corrosion, they become crack nucleation sites which can significantly speed up crack growth rates. In the body's environment the cracks become localized electrochemical cells that promote further corrosion. $\mathrm{Mg}$ in particular is susceptible to corrosion fatigue due to the presence of chloride ions in the body fluids. Corrosion within the crack promotes crack propagation and in combination with cyclic loading, the crack growth rate significantly increases. Eventually the loading stress exceeds the SCC threshold and the crack grows to a critical size resulting in the fracture of the metallic implant. The body environment can significantly reduce the fatigue life of $\mathrm{Mg}$ alloys, producing lower failure stresses and considerably shorter failure times.

\section{Magnesium and its Alloys}

For biomedical applications, the composition of the material being considered is a crucial factor since many of the elements that make up commercially available materials for industrial applications are extremely toxic to the human body. Therefore, in addition to meeting the mechanical properties needed for a particular bio medical application, the material must also be biocompatible. Ideally, a biodegradable biomedical device should be composed of materials or alloys that are non toxic or carcinogenic. It would also be very advantageous if the material was composed of elements and minerals already present and compatible within the body such as magnesium, calcium and zinc, see Table 3. Furthermore, the material should have a controllable dissolution rate or slow corrosion rate that permits the biomedical device or implant to maintain its mechanical integrity until the surrounding tissues heal and are capable of carrying the load once again. After the healing process has taken place, the load bearing properties of the biomed ical implant are no longer required and the implant material should then be able to slowly dissolve away. Furthermore, the resultant by-products of the degradation process should be non-toxic; capable of being consumed or absorbed by the surrounding tissues, or being dissolved and readily excreted through the kidneys. Thus, for $\mathrm{Mg}$ and its alloys to be used as an effective biodegradable implant it is necessary to control their corrosion behaviour in the body flu id environment[121].

\subsection{The Influence of Alloying Elements on Physical and Mechanical Properties}

There are three major groups of $\mathrm{Mg}$ alloys: the first group consists of pure $\mathrm{Mg}$; the second group consists of aluminium (Al) containing alloys such as AZ91, AZ31 and rare earth elements (RE) such as AE21; and the final group consists of the $\mathrm{Al}$ free alloys such as $\mathrm{Mg}-\mathrm{Ca}, \mathrm{WE}, \mathrm{MZ}$ and $\mathrm{WZ}$. The use of alloying elements such Al, Ca, Li, Mn, Y, Zn, Zr and RE in $\mathrm{Mg}$ alloys can significantly improve the physical and mechanical properties of the alloy by: 1) refin ing the grain structure; 2) improving the corrosion resistance; 3) form inter-metallic phases that can enhance the strength; and 4) assist in the manufacture and shaping of $\mathrm{Mg}$ alloys.

Impurities commonly found in $\mathrm{Mg}$ alloys are $\mathrm{Be}, \mathrm{Cu}, \mathrm{Fe}$ and $\mathrm{Ni}$ and the levels of theses impurities are restricted to within specific limits during the production of the alloy, see Table 3. The range of acceptable levels for Be ranges from 2 to $4 \mathrm{ppm}$ by weight, while $\mathrm{Cu}$ is $(100-300 \mathrm{ppm}), \mathrm{Fe}(30-50$ ppm) and Ni (20-50 ppm)[122]. Since both $\mathrm{Be}$ and $\mathrm{Ni}$ are carcinogenic, their use in biomedical applications should be 
avoided as alloying elements. While elements such as $\mathrm{Ca}$, $\mathrm{Mn}$ and $\mathrm{Zn}$ are essential trace elements for human life and RE elements exhibiting anti-carcinogenic properties should be the first choice for incorporation into an alloy. Studies by Song have suggested that very small quantities of RE elements and other alloying metals such as $\mathrm{Zn}$ and Manganese ( $\mathrm{Mn}$ ) could be tolerated in the human body and could also increase corrosion resistance[123]. Mn is added to many co mmercial alloys to improve corrosion resistance and reduce the harmful effects of impurities[124]. Mg alloys containing rare earth elements have also been found to increase the resistance to the flow of $\mathrm{Mg}^{2+}$ ions out of the $\mathrm{Mg}$ matrix via the $\mathrm{Mg}$ oxide layer[125]. During the degradation process the RE elements remained localised in the corrosion layer, which also contained high levels of both calcium and phosphorous. Also during this period a thin amorphous calciu m phosphate layer formed over the surface of the oxide layer[92, 126].

Recent studies by Witte et al. have investigated the degradation behaviour of $\mathrm{Mg}$ based alloy rods and polymer based control rods[poly (lactic acid)] in animal models. Rods of $15 \mathrm{~mm}$ diameter and $20 \mathrm{~mm}$ long were inserted into the femur of guinea pigs and the rods degradation profile monitored. The percentage compositions by weight of the $\mathrm{Mg}$ alloys investigated consisted of two aluminium-zinc alloys composed of 3\% Al and 1\% Zn $\{\mathrm{AZ} 31\}$ and 9\% Al and $1 \% \mathrm{Zn}\{\mathrm{AZ} 91\}$ with the balance of the alloys composed of pure $\mathrm{Mg}$. In addition two RE alloys were studied, the first consisted of $4 \%$ yttrium and a $3 \%$ rare earth mixture composed of neodymium, cerium and dysprosium $\{$ WE43 and the second composed of $4 \%$ lithiu $\mathrm{m}, 4 \%$, a lu miniu $\mathrm{m}$ and a $2 \%$ rare earth mixture of cerium, lanthanum, neodymium and praseodymium $\{$ LAE442\} $[92,127]$. The implants were harvested at 6 and 18 weeks, with complete implant degradation occurring at 18 weeks. During this time radiographs were regularly taken, while a micro-tomography-based technique using X-ray synchrotron radiation was used to characterize the implant's degradation process. All $\mathrm{Mg}$ based alloy implants were found to be beneficial and promoted new in situ bone tis sue formation, while the polymer control rods produced a less significant effect. The LAE442 alloy had the greatest resistance to corrosion, while the other alloys all had similar, but lower values of corrosion resistance and degraded at similar rates [92].

While $\mathrm{Mg}$ is potentially an ideal biocompatible implant material due to its non-toxic ity to the human body, the safe long term use of an $\mathrm{Mg}$ based alloy needs to be carefully studied. Magnesium based alloys have also been used in vivo; for example an AZ91 alloy rods were implanted into the femur of a number of rabbit models and the subsequent analysis revealed that after 3 months the implant had degraded and been replaced by new bone tissue[128, 129]. At the end of this degradation process most of the alloying elements such as Al would have been released into the bodies of the rabbits. The long term health effects on the rabbits are unknown, but in the case of the human body, the release of Al into the body will create undesirable health problems[130]. In humans, Al is a neurotoxicant and its long term accumulation in brain tissues has been linked to neurological disorders such as Alzheimers disease, dementia and senile dementia[131]. In addition, the administration of RE elements such as cerium, praseodymium and yttrium has resulted in severe hepatotoxicity in rats[132]. Furthermore, using heavy metal elements as alloying components are also potentially toxic to the human body due to their ability to form stable complexes and disrupt the normal molecular functions of DNA, enzymes and proteins[133]. Therefore, there is a definite requirement to care fully select alloying elements that are non-toxic to the human body, see Table 4. Non-toxic alloying elements such as $\mathrm{Ca}$ [134] and $\mathrm{Zr}[135]$ have the potential to significantly improve the corrosion resistance of the $\mathrm{Mg}$ alloy and reduce the degradation rate to make the Mg metal alloy a viable implant material[33].

Table 3. Chemical analysis of alloying elements for a select ion of magnesium alloys

\begin{tabular}{|c|c|c|c|c|c|c|c|c|c|}
\hline \multirow[t]{2}{*}{ Alloy } & \multicolumn{8}{|c|}{ Nominal element component (wt. \%) } & \multirow[t]{2}{*}{ Maximum values of trace elements (wt. \%) } \\
\hline & $\mathrm{Al}$ & $\mathrm{Zn}$ & $\mathrm{Mn}$ & $\mathrm{Ca}$ & $\mathrm{Li}$ & $\mathrm{Nd}$ & $\mathrm{Zr}$ & $\mathrm{Y}$ & \\
\hline AZ31 & 3.5 & 1.4 & 0.3 & - & - & - & - & - & $\begin{array}{c}\mathrm{Fe}(\max 0.003), \mathrm{Cu}(0.008), \mathrm{Si}(1.2), \mathrm{Ni}(0.001) \text { and } \mathrm{Be} \\
(5-15 \mathrm{ppm})\end{array}$ \\
\hline AZ91 & 9.5 & 0.5 & 0.3 & - & - & - & - & - & $\begin{array}{c}\mathrm{Fe}(\max 0.004), \mathrm{Cu}(0.025), \mathrm{Si}(0.05), \mathrm{Ni}(0.001) \text { and } \mathrm{Be} \\
(5-15 \mathrm{ppm})\end{array}$ \\
\hline AM60 & 6.0 & 0.2 & 0.2 & - & - & - & & & $\begin{array}{c}\mathrm{Fe}(\max 0.004), \mathrm{Cu}(0.008), \mathrm{Si}(0.05), \mathrm{Ni}(0.001) \text { and } \mathrm{Be} \\
(5-15 \mathrm{ppm})\end{array}$ \\
\hline LAE442 & 4.0 & & & & 4.0 & 2.0 & & & Contains some heavy metal rare earth elements \\
\hline WE43 & - & - & - & - & - & 3.2 & 0.5 & 4.0 & Contains some heavy metal rare earth elements \\
\hline
\end{tabular}

Note: Table compiled from references[92, 93, 216, 217 and 218] 
Table 4. Common alloying elements used in magnesium alloys

\begin{tabular}{|c|c|c|c|}
\hline $\begin{array}{l}\text { Alloying } \\
\text { Element }\end{array}$ & $\begin{array}{c}\text { Mechanical Properties } \\
\text { Enhancement to Mg Matrix }\end{array}$ & Pathophysiology & Toxicology \\
\hline Aluminium & $\begin{array}{l}\text { Rapidly diffuses through } \mathrm{Mg} \\
\text { matrix, and acts as a } \\
\text { passivating element and } \\
\text { improves corrosion } \\
\text { resistance. } \\
\text { Improves die cast-ability }\end{array}$ & Blood serum level 2.1-4.8 $\mu \mathrm{g} / \mathrm{L}$ & $\begin{array}{c}\text { Tends to diffuse out of Mg matrix } \\
\text { Neurotoxic (influences function of the } \\
\text { blood brain barrier) } \\
\text { Linked to Alzheimer's disease } \\
\text { Accumulates in amyloid fibres/brain } \\
\text { plaques. } \\
\text { Accumulates in bone tissue/decreases } \\
\text { osteclast viability }\end{array}$ \\
\hline Calcium & $\begin{array}{l}\text { Adding to improve } \\
\text { corrosion resistance in } \\
\text { Mg-Ca alloys. }\end{array}$ & $\begin{array}{l}\text { Blood serum level } 0.919-0.993 \mathrm{mg} / \mathrm{L} .- \\
\text { Levels controlled by Homeost at is of } \\
\text { skeleton. Abundant mineral that is } \\
\text { mainly stored in bones and teeth. } \\
\text { Activat or/stabilizer of enzymes. } \\
\text { Involved in blood clotting }\end{array}$ & $\begin{array}{l}\text { Metabolic disorder of calcium levels results } \\
\text { in the formation of excess calcium in the } \\
\text { kidneys (stones). }\end{array}$ \\
\hline Copper & $\begin{array}{l}\text { Can increase strength of } \mathrm{Mg} \\
\text { casts, however, it also } \\
\text { accelerat es corrosion rate } \\
\text { when exposed to a } \mathrm{NaCl} \\
\text { medium. } \\
\end{array}$ & $\begin{array}{l}\text { Blood serum level } 74-131 \mu \mathrm{mol} / \mathrm{L} \\
\text { Essentialtrace element }\end{array}$ & $\begin{array}{l}\text { Excessive amounts of Cu have been linked } \\
\text { to neuro-degenerative diseases. } \\
\text { Can produce cellular cytotoxicity. }\end{array}$ \\
\hline Manganese & $\begin{array}{l}\text { Adding to reduce the } \\
\text { harmful effects of impurities } \\
\text { and improve corrosion } \\
\text { resistance }\end{array}$ & $\begin{array}{c}\text { Blood serum level } \varangle 0.8 \mu \mathrm{g} / \mathrm{L} \\
\text { Essentialtrace element } \\
\text { Influences cellular funct ions/immune } \\
\text { system/blood clott ing/bone growth. } \\
\text { Influences metabolic cycle of } \\
\text { lipids/amino acids and carbohydrates }\end{array}$ & $\begin{array}{l}\text { Excessive amounts of Mn can produce } \\
\text { neurological disorder. (manganism) }\end{array}$ \\
\hline Lithium & $\begin{array}{l}\text { Improvement in corrosion } \\
\text { resistance }\end{array}$ & $\begin{array}{c}\text { Blood serum level 2-4ng/g } \\
\text { Used in drugs to treat psychiatric } \\
\text { disorders } \\
\end{array}$ & $\begin{array}{l}\text { Overdose causes central nervous centre } \\
\text { disorders, lung dysfunctions, impaired } \\
\text { kidney function. }\end{array}$ \\
\hline $\begin{array}{l}\text { Rare earth } \\
\text { Elements }\end{array}$ & $\begin{array}{l}\text { Improvement in corrosion } \\
\text { resistance }\end{array}$ & $\begin{array}{l}\text { Many rare earth elements have } \\
\text { anticancerogenic properties and are used } \\
\text { in the treatment of cancer. }\end{array}$ & Accumulate in the liver and bone \\
\hline Zinc & $\begin{array}{l}\text { Improves yield stress, } \mathrm{Mg} \\
\text { alloys containing } \mathrm{Zn} \text { have an } \\
\text { Elastic Modulus similar to } \\
\text { bone. } \\
\text { The presence of } \mathrm{Zn} \text { can } \\
\text { reduce hydrogen gas } \\
\text { evolution during } \\
\text { bio-corrosion. }\end{array}$ & $\begin{array}{c}\text { Blood serum level } 12.4-17.4 \mu \mathrm{mol} / \mathrm{L} \\
\text { Essentialtrace element } \\
\text { Essentialto enzymes and immune } \\
\text { system }\end{array}$ & $\begin{array}{l}\text { In high concentrat ions is neurotoxic and can } \\
\text { hinder bone development. }\end{array}$ \\
\hline
\end{tabular}

Note: Table compiled from references[122, 134, 213, 222, 223, 224, 225, 226227 and 228]

\section{Surface Modifications and Treatment Processes for Biomedical Mg Alloys}

The high degradation rate of $\mathrm{Mg}$ and $\mathrm{Mg}$ alloy implants in the human physiological environment would result in the reduction of mechanical integrity of the implant before the bone tissues had sufficient time to heal[26]. There are two methods of reducing the degradation rate; the first, which was discussed in Section 3, involved alloying $\mathrm{Mg}$ with biocompatible elements that can resist the corrosion process. The second method is discussed in this section and involves the surface modification of the implant, through a treatment process that provides a resistive barrier against the body environment. An important factor that needs to be taken into account before any surface treatment is investigated is the healing or regenerative processes of bone and other associated body tissues. The healing process consists of three phases; inflammatory, reparative and remodelling.

The in itial inflammatory phase usually lasts between 3 to
7 days and this is the natural response of the body's immune system to the presence of the biomedical device or implant. The reparative phase usually takes 3 to 4 months, during which time integration of the implant with the new and regenerated tissues takes place. The final remodelling phase, which is the longest phase, can take from several months to years to complete[136]. For $\mathrm{Mg}$ to be an effective bio-absorbable implant the degradation rate must be slow enough for the healing process to take place and the new tissues have sufficient time to provide their own structural support before the structural integrity of the implant is compromised. The minimum period for this to take place is at least 12 weeks[26]. Unfortunately, $\mathrm{Mg}$ alloys can completely degrade before the end of this time frame and as a result there is a need to reduce the biodegradation rate. The bulk properties of $\mathrm{Mg}$ based alloys dictate its mechanical properties, but it is the surface properties that influence the interaction between the metal and the surrounding tissue environment of the body. As a consequence, surface 
modifications and treatments can have a significant role to play in governing the degradation rate of the implant. To date, numerous surface modification techniques have been developed to change the surface characteristics of biomaterials. Many of these methods have been applied to modifying the surface properties of $\mathrm{Mg}$ bio-alloys. A brief overview of some of these surface modification processes are presented in the following the four sections.

\subsection{Mechanical Modifications to Induce Surface and Subsurface Properties}

The surface structure of an implant is very important, since it is the initial response of the surrounding tissues to the surface of the implant material that determines whether or not there is effective tissue-biomaterial integration. Studies of conventional types of permanent implant materials have shown that surface roughness can influence both cell morphology, cell growth and implant integration. In addition, modification of the surface topography by the physical placement of grooves, columns, pits and other depressions can influence cell orientation and attachment[137-139]. In the case of Ti alloys, surface modifications such as grooves, surface sand blasting and acid etching has revealed that grooved surface features provide superior cell attachment and promote greater cell proliferation than roughen surfaces[140]. For Mg alloys, the influence of different mechanical processing operations during fabrication has the potential to greatly influence surface and subsurface properties [141, 142].

Mechanical processing techniques involve operations such as rolling, shot peening, and milling. In the case of milling, at low cutting speeds, the surface formed by honed cutting tools tends to produce a rougher surface than those of sharp cutting tools. Also, during milling and similar metal chip removing processes, the exact effect on the underlining sub-surface is not fully understood[143], while chip removal fro $m$ the surface during machining can directly influence the surface topography[144]. Besides machining techniques for chip removal, the use of rolling operations can also generate high passive forces acting normal to the surface, which can induce work hardening of the sub-surface. During the rolling operation the sub-surface grain structure is changed by the compressive stresses induced and the resultant micro-topography of the surface is significantly changed[145]. A recent study by Denka et al. has revealed a significant reduction in the corrosion rate (a factor of 100 was achieved in corrosion studies) of an $\mathrm{Mg}-\mathrm{Ca}$ alloy that was deep-rolled, compared to the same alloy that was machined[146]. The presence of residual compressive stresses after rolling also has the advantage of reducing micro-crack formation from pre-existing crack nucleation points within the substrate. The suppression of crack formation is also an important factor in improving the fatigue life cycle of a material being considered for biomedical applications [146, 147].

The importance of surface and sub-surface treatments on
$\mathrm{Mg}$ alloy implants was recently investigated by Von Der Hoh et al.[148]. In their study three surface machining treatments were applied to an $\mathrm{Mg}-\mathrm{Ca}(0.8 \%$ wt calcium) alloy. The alloy was used to make three different geometric sample types. The first test sample was a machined $3 \mathrm{~mm}$ diameter smooth cylinder, the second was like the first, except that it was sand blasted for $30 \mathrm{~s}$ using particles ranging in size from 300 to $400 \mu \mathrm{m}$ and the final surface topography was a threaded cylinder. The smooth cylinders were machined with no further surface treatment, so they retained the micro-surface topography produced by the cutting tool. After 6 months of in vivo implantation in adult New Zealand white rabbits, the smooth cylinders revealed good integration with the surrounding tissues and also had the least structural loss. The sand blasted cylinders had the greatest material loss with the initial cylindrical shape completely consumed, while the threaded cylinders ranged between these two extremes. The results indicated that the smoother mic ro-topographic surface features of the cylinders were suitable for resorbable $\mathrm{Mg}$ alloys, while the test samples with the rougher surfaces promoted higher degradation rates. The results of this study clearly indicated that differences in surface roughness of the test samples could significantly influence the in vivo degradation rates. The study also highlighted the need for further investigation into the effects of different surface modifications on other biocompatible $\mathrm{Mg}$ alloys.

\subsection{Physical and Chemical Modifications}

From an engineering point of view, the most effective way to prevent corrosion is to coat the metal component with a protective barrier that effectively isolates the metal from the surrounding environment. To be effective against corrosion, the protective coating must be uniform, well adhered and free from any imperfections such as pits, scratches and cracks. The major problem with $\mathrm{Mg}$, as mentioned earlier, is its chemical reactivity when exposed to air or an aqueous environmental which results in the formation of an oxide/hydroxide layer over the metal surface. The presence of the oxide/hydroxide layer will have a detrimental effect on the ability of the coating to adhere to the metal surface and form a uniform protective layer. Therefore, surface cleaning and a suitable pre-treatment of the metal surface is a crucial factor in achieving an effective surface coating.

\subsubsection{Physical Vapour Deposition (PVD) \& Chemical Vapour Deposition (CVD)}

The PVD process involves the deposition of thin layers of metal and metal alloys from atoms or molecules from the vapour phase onto a substrate surface. During the process a metal or metal alloy is heated in vacuum chamber until it evaporates and then the subsequent vapour condenses onto the cooler substrate. This process has been successfully used on a variety of metals, but in the case of $\mathrm{Mg}$ there are a number of problems to overcome. For example, in most PVD processes the substrate temperature range is usually between 
400 and $550{ }^{\circ} \mathrm{C}$, but in the case of $\mathrm{Mg}$ the substrate temperature must be kept below $180^{\circ} \mathrm{C}$ for material stability reasons. The lower substrate temperature of $\mathrm{Mg}$ also influences the adhesive and corrosion resistance properties of the coating $[149,150]$. The PVD process has successfully deposited binary alloys such as $\mathrm{Mg}-\mathrm{Ti}, \mathrm{Mg}-\mathrm{Zr}$ and $\mathrm{Mg}-\mathrm{Mn}$ along with other less biocompatible and toxic alloys. The subsequent corrosion studies have revealed that the binary-alloyed surface coating were capable of increasing the corrosion resistance of the various Mg alloys[151-153]. The chemical vapour deposition process has also been used to produce a variety of coating processes that can create a protective coating or modify the existing $\mathrm{Mg}$ alloy surface. During the deposition of a solid material from the vapour phase onto a (usually) heated substrate a chemical reaction over the surface takes place. This results in changes to the sub-surface of the substrate, which chemically modifies the surface properties. For example, the deposition of diamond like carbon (DLC) films on metallic implants can improve the surface properties of the implant, thus making it biocompatible with the surrounding body tissues[154].

\subsubsection{Ion Imp lantation and Plating}

Ion implantation consists of bombarding the surface of a substrate with ionized particles. The ionized particles penetrate the surface and become embedded in the sub-surface of the substrate. The ionized particles soon neutralize in the interstitial positions within the grain structure forming a solid solution. During this process physiochemical changes take place in the sub-surface of the substrate, while the bulk properties of the substrate remain unchanged. To date there have been relatively few studies carried out that have used ion implantation to enhance the surface properties of Mg alloys. A recent study by Liu et al. examined the corrosion behaviour of surgical AZ91 after it was subjected to $\mathrm{Ti}$ ion implantation[155]. The study revealed that a compact surface oxide layer was formed, which was predominantly composed of $\mathrm{TiO}_{2}$ with a smaller amount of $\mathrm{MgO}$. Subsequent testing in simulated body flu id at $37 \pm 1{ }^{\circ} \mathrm{C}$ revealed that the corrosion resistance of ion treated AZ91 alloy was improved significantly. In a similar study by Fang et al. the corrosion behaviour of a new medical grade $\mathrm{Mg}-\mathrm{Ca}$ alloy was examined before and after $\mathrm{Zn}$ ion implantation[156]. The results revealed that after ion implantation, the $\mathrm{Zn}$ had improved the surface hardness and elastic modulus of the alloy. The surface oxide layer formed during corrosion testing in simulated body fluid enhanced the $\mathrm{Mg}-\mathrm{Ca}$ alloys corrosion resistance. However, Wan et al. examined a $\mathrm{Mg}-\mathrm{Ca}$ alloy before and after $\mathrm{Zn}$ ion implantation, the results found that the ion-implanted substrates had a lower corrosion resistance than the untreated substrates[157]. Subsequent analysis of the results suggests that $\mathrm{Zn}$ was an unsuitable metal for ion implantation with $\mathrm{Mg}$-Ca alloys for biomedical applications.

Ion plating is a technique that deposits noble metal ions onto a less noble metal substrate to form a dense and well-adhered layer. The plating layers improve surface properties such as topography, roughness, surface chemistry and wear resistance. Zhang et al. used this technique to plate a pure $\mathrm{Mg}$ substrate with $\mathrm{Ti}$ ions and then subsequently studied its corrosion behaviour in a 0.9 wt $\% \mathrm{NaCl}$ solution[158]. The results not only revealed a substantial improvement in corrosion resistance, but also found that an interfusion layer had formed between the Ti coating and the Mg substrate.

\subsubsection{Thermal Spray Coatings}

During this coating process, materials such as metals, metal alloys, ceramics, polymers and composites are feed (powder or wire form) into a gun. The material is then heated to a molten or semi molten state within a gas stream. The resulting micro meter size droplets are accelerated in the gas stream, which is directed towards the surface of the substrate[159]. This technique was successfully used by Zhang et al. to deposit an Al layer on an AZ91D substrate[160]. To ensure adhesion of the coating to the substrate, a post heat treatment process was carried out $450^{\circ} \mathrm{C}$. There was significant diffusion of $\mathrm{Al}$ and $\mathrm{Mg}$ around the interface of the coating, which enhanced both the corrosion resistance and anti-wear properties of the coating. The disadvantage of using an Al coating on the AZ91D substrate for a possible biomedical implant application is the negative effect of $\mathrm{Al}^{3+}$ ions being released into the surrounding tissues during subsequent corrosion. Ceramic coatings such hydroxyapatite (HAP), $\mathrm{TiO}_{2}, \mathrm{Al}_{2} \mathrm{O}_{3}$, and $\mathrm{ZrO}_{2}$ have also been successfully applied to Ti alloys to improve their corrosion resistance, wear resistance and biocompatibility[161]. However, in a study by Zeng et al., thermally sprayed $\mathrm{TiO}_{2}$ onto an $\mathrm{Mg}$ alloy (AM60) revealed that the subsequent coating showed no improve in its corrosion resistance compared to the untreated $\mathrm{Mg}$ alloy when they were both immersed in Hanks' solution[162]. The study also revealed that galvanic corrosion occurred between the surface of the $\mathrm{Mg}$ alloy and the coating layer, which effectively reduced any protective properties offered by the coating. This highlights the weakness of thermally sprayed ceramic coatings which have rough surfaces, high porosity and poor adhesion properties[163].

\subsubsection{Laser Surface Melting, Alloying and Cladding}

The high-density energy of a laser beam can be effectively used to modify the surface region of $\mathrm{Mg}$ alloys. The surface region of the alloy can be melted to create a meta-stable solid solution. This is then followed by rapidly cooling the substrate, which results in the refinement of the surface microstructure. This technique can also be used to improve the surface properties of an $\mathrm{Mg}$ alloy substrate by melting a metallic coating and the underlining sub-surface. During the rapid melting process both the coating and sub-surface mix before re-solidifying during subsequent cooling to form a new surface alloy which coats the bulk of the substrate. Furthermore, if the appropriate alloying metals are 
incorporated into this surface modification technique it is possible to significantly improve surface properties such as corrosion resistance[164, 165]. For example, improved surface properties of a Mg alloy (AZ91) have been achieved with the dispersion of hard metallic particles such as $\mathrm{TiC}$ and $\mathrm{SiC}$ in the molten pool generated by laser melting $[166,167]$. Also, laser cladding of an Al-Si alloy onto a number of $\mathrm{Mg}$ alloys such as AS41, AZ91 and WE54 have also been attempted, but unfortunately, the surface properties were not significantly improved[168, 169].

\subsection{Wet Che mical Processes}

\subsubsection{Electroche mical Deposition of Metallic Coatings}

The corrosion resistance of $\mathrm{Mg}$ and its alloys can be increased by an electroplating technique. In this technique a metal salt is reduced in solution to its metallic form, the electrons for reduction are supplied from an external source and the resulting metallic ions are deposited on to the surface of the substrate. However, most metals are more electrochemically noble than $\mathrm{Mg}$, which can cause serious problems if there are any imperfections in the deposited layer. Such imperfections will expose the underlining substrate and result in the formation of s mall localized areas of corrosion. The corrosion sites form highly corrosive pits that tunnel down into the $\mathrm{Mg}$ substrate and seriously weaken the substrate[141]. From an industrial point of view, electroplating is a highly effective technique for coating $\mathrm{Mg}$ and its alloys with metallic coatings such as nickel, ch rome and aluminium coatings[142]. These coatings have good mechanical properties and provide effective corrosion protection. Unfortunately, these metals are also harmful to human tissues, which make them highly unsuitable for biomedical applications.

\subsubsection{Chemical Conversion Coatings}

Chemical conversion coatings are formed by chemically treating the surface of $\mathrm{Mg}$ and $\mathrm{Mg}$ alloys to produce a thin outer coating of metal oxides, phosphates or other compounds that are chemically bonded to the surface[170]. The conversion coating acts as protective barrier that is olates the substrate from the surrounding environment and prevents the corrosion.

Industrially, there are several different types of conversion coatings such as chromate, phosphate/permanganate, rare earth, stannate and hydrides. Many of the processes used to produce conversion coatings involve the use of toxic materials that are detrimental to human health. For example, the presence of hexavalent chromium $\left(\mathrm{Cr}^{6+}\right)$, that is used in chromate coatings.

An alternative treatment to chromate conversion coatings are: 1) phosphate; 2) phosphate-permanganate; and 3) stannate coatings. All three of these conversion treatments have comparable corrosion resistant properties to those of chromate treatments. Xu et al. have investigated the behaviour of a phosphate treatment on an $\mathrm{Mg}$ alloy
(Mg-Mn-Zn) that was subsequently immerged in a simulated body solution (SBF). During the treatment process a biocompatible brushite layer[ $\left.\mathrm{CaHPO}_{4} \cdot 2 \mathrm{H}_{2} \mathrm{O}\right]$ was formed on the surface of the substrate. Subsequent immersion in SBF revealed that the brushite layer transformed into a coating of HAP, with the excess phosphate ions being released into the surrounding environment. The released phosphate ions were also found to neutralize the alkalization effect produced by the corrosion process. The treatment process did not prevent corrosion, but it did significantly slow down the degradation rate[171]. And a phosphate-permanganate process developed by Han et al. using $\mathrm{Mn}_{3}\left(\mathrm{PO}_{4}\right)_{2}$ was able to produce a resilient surface coating on a $\mathrm{Mg}$ alloy (AZ31D) that was self healing in saline solutions[172]. While a stannate treatment developed by Gonzalez-Nunez et al. was able to deposit a 2 to $3 \mu \mathrm{m}$ thick layer of $\mathrm{MgSnO}_{3}$ on an $\mathrm{Mg}$ alloy (ZC71). The coating was adherent, continuous, and crystalline which produced a passivating effect on the substrate surface[173]. Unfortunately, no degradation rate data was reported, indicating that more studies are needed to indeed gauge the effectiveness of this process for in vivo applications.

Magnesium fluoride $\left(\mathrm{MgF}_{2}\right)$ conversion coatings on $\mathrm{Mg}$ alloys have produced mixed results in providing corrosion protection. Degradation studies carried out by Zeng et al. reported that an $\mathrm{MgF}_{2}$ conversion layer formed on an $\mathrm{Mg}$ alloy (AZ31) provided marg inal corrosion resistance in a 0.9 wt $\% \mathrm{NaCl}$ solution[174]. While in a similar study Hassel et $a l$. found that a conversion layer of $\mathrm{MgF}_{2}$ formed on an $\mathrm{Mg}$ alloy (ZM21) could provide reasonable corrosion resistance[175]. And an in vivo study carried out by Witte et al. revealed that a conversion layer thickness between 150 and $200 \mu \mathrm{m}$ formed on the surface of a RE based Mg alloy (LAE442) was able to reduce the degradation rate and reduce the release of alloying elements[176]. In a similar study by Gao et al., the feasibility of forming RE conversion layers on pure $\mathrm{Mg}$ to improve corrosion resistance was examined[177]. The two RE elements under investigation were $\mathrm{Ce}$ and $\mathrm{Y}$, with each element being used individually to form a surface treatment solution. The first solution contained $\mathrm{CeCl}_{3}$ which formed a conversion layer cons isting of $\mathrm{Mg}(\mathrm{OH})_{2}, \mathrm{CeO}_{3}$ and $\mathrm{MgO}$, while the second solution contained $\mathrm{Y}\left(\mathrm{NO}_{3}\right)_{2}$ which formed a conversion layer consisting of $\mathrm{Mg}(\mathrm{OH})_{2}, \mathrm{Y}_{2} \mathrm{O}_{3}$ and $\mathrm{MgO}$. The study revealed that the second conversion layer had improved corrosion resistance compared to the first. However, both coating provided limited corrosion resistance due to their thin thickness and soft structure, which was incapable of withstanding minor mechanical damage. Furthermore, both the toxicology and metabolic pathways within the human body of RE elements such as Ce and Y are still unclear and need to be fully investigated before they can be used in biomedical applications.

\subsubsection{Calcium Phosphate Surface Coatings}

A more biocompatible form of conversion coating can be derived from a variety of calcium phosphate compounds. In 
particular, HAP $\left[\mathrm{Ca}\left(\mathrm{PO}_{4}\right)_{6}(\mathrm{OH})_{2}\right]$, which has been widely used as a bone substitute and replacement in several biomedical applications[178-180]. There are three major advantages in using HAP in hard tissue engineering applications: 1) it has good biocompatibility and bioactivity properties with respect to bone cells and other body tissues; 2) it has a slow biodegradability in situ; and 3) it offers good osteoconductivity and osteoinductivity capabilities[181, 182]. These properties are very important because bone tissue constantly undergoes remodelling, a process in which bone tissue is simultaneously replaced and removed by the bone cells, (osteoblasts and osteoclasts respectively). It is these advantages that make HAP and TCP (tri-calcium phosphate) compounds attractive for coating metallic orthopaedic implants. In this application, both HAP and TCP coatings promote bone formation which enhances bonding between the implant and the surrounding tissues.

It is also due to these positive biological responses within the human body that has made calcium phosphate coating an attractive option for potentially reducing the biodegradation rate of $\mathrm{Mg}$ orthopaedic implants. Several techniques have been used to deposit calcium phosphate coatings onto $\mathrm{Mg}$ substrates, these range from anodization[183], bio-mimet ic co atings [184-186], electro-deposition[187,188], hydrothermal [189] and wet chemical methods [190, 191].

$\mathrm{Xu}$ et al. has investigated using an immersion technique that involves soaking an $\mathrm{Mg}-\mathrm{Mn}-\mathrm{Zn}$ alloy in an alkaline solution to form a brushite $\left(\mathrm{CaHPO}_{4} \cdot 2 \mathrm{H}_{2} \mathrm{O}\right)$ surface coating. Unfortunately, the layer formed was porous and did not prevent corrosion in a simulated body fluid. However, the degradation rate was significantly reduced and provided the $\mathrm{Mg}$ alloy substrate with reasonable protection against the corrosive effects of the simulated body fluid. The study also found that the brushite coating was able to improve the surface biocompatibility of $\mathrm{Mg}$ alloy substrate, since the brushite coating transformed into a HAP phase with time. Also during this transformation, acid ic phosphate ions were released into solution, which tended to have a neutralizing effect on the alkalization process[192]. Furthermore, the surface treatment enhanced the bioactivity of the Mg-Mn- $\mathrm{Zn}$ alloy and promoted bone formation[193].

A similar calcium-phosphate coating was produced by Wang et al., which involved immersing a $\mathrm{Mg}$ substrate into a solution containing $\mathrm{Ca}$ and $\mathrm{P}\left[\mathrm{Ca}\left(\mathrm{NO}_{3}\right)_{2}\right.$ and $\left.\mathrm{Na}_{2} \mathrm{HPO}_{4}\right]$ to create a di-calcium phosphate di-hydrate (DCPD) surface layer[194]. The DCPD layer was effective in providing protection for the Mg substrate during the first 21 days of immersion in a simulated body fluid.

Recently, Yanovska et al. investigated the influence of low magnetic fields during a one-step dipping technique [195]. The involved dipping a $\mathrm{Mg}$ substrate into an aqueous solution containing $\mathrm{Ca}\left(\mathrm{NO}_{3}\right)_{2} \cdot 4 \mathrm{H}_{2} \mathrm{O}$ and $\mathrm{Na}_{2} \mathrm{HPO}_{4} \cdot 12 \mathrm{H}_{2} \mathrm{O}$. Deposition of both DCPD and HAP phases under the influence of magnetic fields lead to crystalorientation during the formation of the phases. The technique also produced coatings with enhanced corrosion resistance, which in turn reduced the degradation rate[195]. In an alternative method,
Song et al. used an electro-deposition technique to produce three types of coating namely; DCPD, HAP and fluorapatite (FHA). The study found the FHA coating had long-term stability and remained intact even after 1 month of immersion in a simulated body fluid and provided effective corrosion resistance to the $\mathrm{Mg}$ alloy[196].

\subsubsection{Alkali Heat Treatments}

Heat treatment can be a beneficial way of improving the microstructure and enhance the surface properties of $\mathrm{Mg}$ and $\mathrm{Mg}$ alloys. The corrosion behaviour and cytotoxicity of alkali heat-treated pure $\mathrm{Mg}$ samples immersed in simulated body fluid (SBF) were investigated by Li et al.[197]. The samples for treatment were placed into a super saturated $\mathrm{NaHCO}_{3}-\mathrm{MgCO}_{3}$ solution and then heat-treated. SBF solutions with and without chloride ions were used to study the influence of chloride ions on the corrosion behaviour of treated $\mathrm{Mg}$ samples. All the treated samples showed a significant imp rovement in corrosion resistance in both SBF $\left(\mathrm{Cl}^{-}\right)$and $\mathrm{SBF}$ solutions compared to the untreated $\mathrm{Mg}$ samples. In addition, after 14 days of immersion in the SBF flu ids, a calcium phosphate compound with a molar ratio of 1.858 was detected on the surface of the samples. While the subsequent cytotoxicity testing revealed no signs of morphological changes in the cells and no inhibitory effect of the surface treatments on cell growth could be detected.

In a similar study by Liu et al., the corrosion behaviour of a heat-treated Mg-Al alloy (AZ63) immersed in a SBF solution for 14 days was investigated[198]. During heat treatment (solution treatment at $413^{\circ} \mathrm{C}$ for $24 \mathrm{~h}$ followed by aging at $216^{\circ} \mathrm{C}$ for intervals of $1 \mathrm{~h}, 5.5 \mathrm{~h}$ and $12 \mathrm{~h}$ ), the microstructure of the $\mathrm{Mg}-\mathrm{Al}$ alloy changes as the $\mathrm{Al}$ atoms in the alloy diffuse towards the grain boundaries and subsequently precipitate out of solution to form the $\beta$ phase. And as a consequence of the diffusion process (Aging), the concentration of $\mathrm{Al}$ atoms remain ing in the matrix ( $\alpha$ phase) decreases and results in the matrix having a reduced corrosion rate. In addition, the study found that samples microstructure significantly influenced the overall corrosion morphology. For example, the surface of the untreated samples displayed deep and uniform corrosion, while the surface of the treated samples had only shallow pitting[198].

\subsubsection{Anodization}

The anodization of magnesium is an electro-chemical process that changes the surface chemistry of the metal, via oxidation, to produce a stable anodic oxide layer. The structure of this layer is characterized by a thin barrier layer at the metal-oxide interface, followed by a less dense porous oxide layer. The porous layer can display a variety of different structures and properties which are dependent on the composition, substrate micro-structure and processing parameters[142]. The processing parameters that influence oxide layer formation include: 1) the type, temperature and concentration of electrolyte; 2) current density; and 3) the applied anodization voltage. These parameters can also 
significantly influence the resulting corrosion behaviour of the substrate[199]. The anodization process can also produce an oxide layer consisting of pores, whose size and density is dependent on the selection of the appropriate processing parameters. Industrially, porous oxide layers are usually coloured and then sealed or form part of a pre-treatment process prior to painting or coating. Many of the industrial coating and surface treatments used on anodized Mg alloy components to reduce corrosion are toxic to the human body. And as a result, research efforts have focused on searching for biocompatible surface treatments and process that are non toxic. For example, Hiromoto et al. have studied the effects of controlled calcium phosphate $(\mathrm{Ca}-\mathrm{P})$ precipitation on pure $\mathrm{Mg}$ substrates by anodization and then thermally treating the substrates in an autoclave[200]. After thermal treatment, the subsequent immersion studies in Hanks' solution revealed that the Ca-P coated substrates had very little corrosion[201]. The advantage of this technique comes from the $\mathrm{Ca}$ and $\mathrm{P}$ elements being deposited on the substrate, since both bioactive materials are known to induce osteoinduction and promote new bone tissue growth[201].

Micro-arc oxidation (MAO) is an electrochemical process which uses a high anodic voltage and high current density to create an intense micro-arc (plas ma) near the metal surface to induce oxidation. The oxide layer formed during this process is substantially thicker than conventional anodization, since the sub-surface of the metal substrate is also oxidized[202]. This technique can be used to deposit ceramic coatings on valve metals such as $\mathrm{Al}, \mathrm{Mg}, \mathrm{Ta}, \mathrm{Ti}, \mathrm{W}$, $\mathrm{Zn}$ and $\mathrm{Zr}$ and their alloys. And by selecting the appropriate process parameters, the (MAO) technique can produce high quality coatings with superior adhesion, corrosion resistance, micro-hardness, wear resistance and strength. In a corrosion and wear study by Zhang et al., die cast Mg alloy (AZ91D) substrates were treated with a MAO coating. Then both treated and untreated substrates were immersed in the Hanks' solution to determine the effectiveness of the MAO coating in reducing the corrosion rate[203]. Immersion testing revealed that the untreated substrates loss 15 times more mass due to corrosion than the MAO treated substrates. In addition, the mass loss from the untreated substrates during wear tests was 1.5 times greater than those of the MAO treated substrates. The tests clearly indicated that the MAO surface treatment was effective in improving both the corrosion and wear resistance of the $\mathrm{Mg}$ alloy. Unfortunately, there is no current data available describing the combined effects of corrosive and wear on MAO treated Mg alloys in Hanks solution.

In a recent study examining the combined effects of corrosion and wear on an Mg Alloy (AZ91), Chen et al., investigated untreated and MAO treated substrates immersed in different composition based solutions composed of $\mathrm{NaCl}$ and $\mathrm{NaHCO}_{3}[204]$. The study revealed that the MAO coating did improve the corrosion resistance of the $\mathrm{Mg}$ alloy. However, the wear resistance of the treated substrate tended to decrease with time. The decreasing wear resistance was caused by wear debris, wh ich consisted of abrasive particles produced by the breakdown of the MAO coating. Both anodization and MAO oxide coating can effectively reduce the corrosion rate of $\mathrm{Mg}$ and $\mathrm{Mg}$ a lloys by producing a strong resilient oxide layer that provides an effective protective barrier between the metal substrate and the fluid environment. For examp le, Song et al. has demonstrated that the oxide layer produced during the anodizat ion of a pure $\mathrm{Mg}$ substrate was capable of providing an effective barrier to corrosion for 1 month in Hanks' solution. During this time no hydrogen evolution was detected, indicating that the degradation had been delayed[205, 206]. This is an important factor for a biodegradable implant, since controlling the dissolution rate allows matching of the degradation rate of the implant with the growth of new replacement bone tissue.

\subsection{Pol ymer Coatings}

Many implantable biomedical devices and implants are coated with a thin adherent polymeric material that effectively isolates the device from the flu idic environment of the body. Poly mer coatings are frequently used to modify the surface properties of biomedical implants to improve their biocompatibility, performance and therapeutic effectiveness. The interface between implant surface and body environment is critical in soliciting the appropriate immunological response. Therefore, selecting the correct polymer coating is crucial in determining the biocompatibility of the implant and also provides a wider range of design options that can be used to improve the surface properties of the original implant surface. For example, selecting a polymer coating which slowly biodegrades can potentially delay the corrosion of an $\mathrm{Mg}$ implant and maintain its mechanical integrity over a longer timeframe.

Biomedical coatings can be divided into two primary categories: 1) short term, which include disposable or single patient use; and 2) long term application of prosthetic implants and reusable laboratory equipment[207]. To achieve the bio-functional requirements and protection, a successful polymer coating must adhere to the Mg implant and be strong and flexible enough to withstand the normal movement of the implant. The coating should also be capable of being sterilised and be sufficiently durable to perform its protective function under the expected conditions of the particular application[208]. The advantage of polymer coatings is that they can be chemically, physically and mechanical customized to suit a specific application. Thus, being able to select and fine-tune the various properties has enabled polymeric materials to be used in a wide range of coating applications such as protection, improved lubricity, antimicrobial, adhesion resistance, ultrasonic imaging and blood compatible coatings for drug delivery [209].

Before coating, an appropriate pre-treatment process is required to effectively clean the surface of the $\mathrm{Mg}$ implant. This process should produce a clean, dry and contaminant free surface capable of providing the maximum possible 
adhesive strength between the polymer and implant surface. The presence of entrapped air and mo isture on the surface could lead to degassing and the formation of holes in the coating during the curing process. The coating process and associated coating parameters can influence the resulting microstructure and morphology of the polymer coating. This explains why coatings with similar compositions can have different surface properties[210]. A polymer coating can be applied to an $\mathrm{Mg}$ implant using a solvent, an aqueous solution or from the vapour phase. Water based coating techniques have the advantages of eliminating or reducing solvent effects on the substrate and are more environmental friendly, since there are no toxic solvent wastes produced. Poly mer coating produced by vapour-deposition can produce both uniform and defect-free coatings. The quality and chemical structure of these coatings combine to provide an effective barrier to the body environment and also enhance the protective properties of the coating. For example, Parylene (poly ( $\mathrm{p}$-xylylene), is a polymer coating that has been used to protect implanted sensors and other biomedical devices[210].

In addition, $\mathrm{Mg}$ needs a suitable surface primer or binding agent to improve the adhesion between the poly mer coating and the implant surface. Unfortunately, primers composed of metallic ions, components of binding agents and almost all organic solvents found in paints and similar surface preparations are to xic or detrimental to the human body and therefore cannot be used in biomedical applications. Recently, Huang et al. primed a pure Mg substrate using a silane coupling agent before using dip coating technology to coat the substrate with degradable poly (lactic acid)[211]. The silane coupling agent was found to improve the adhesion between the poly (lactic acid) and the substrate. Similarly, PLGA, a polymer with good blood compatibility was also coated onto a pure $\mathrm{Mg}$ substrate using the same process. Subsequent corrosion testing in Hanks solution revealed that the PLGA could provide an effective coating and protect the underlining $\mathrm{Mg}$ substrate. However, corrosion protection of the $\mathrm{Mg}$ substrate was dependent the degradation of the PLGA. And in a bone replacement application, the coating was unable to provide an adequate protective barrier[211]. In a similar study, $\mathrm{Xu}$ et al. was able to show that producing different surface modifications on chitosan coatings applied to $\mathrm{Mg}$ alloy substrates were able to influence the biodegradability of the coating[212].

Polymeric coatings have the potential to modify the surface properties of an $\mathrm{Mg}$ based implant and significantly improve the implants usability, durability and performance. Polymeric materials used in coating an implant have the potential to be specifically designed to provide physical, chemical and mechanical responses that can be fine-tuned to solicit and enhance specific biochemical responses within the body environment. However, a significant research effort is still needed to find polymeric materials that can produce thin, dependable, multi-functional coatings with controllable degradation rates that can be used to prolong the mechanical effectiveness of $\mathrm{Mg}$ based implants.

\section{Conclusions}

$\mathrm{Mg}$ and $\mathrm{Mg}$ based alloys are extremely biocompatible and have similar mechanical properties to natural bone. This makes them an attractive material for the manufacture of biodegradable, with the capability to replace many currently used orthopaedic materials such as biodegradable biopolymers. And despite having the potential to function as an osteoconductive and biodegradable substitute in load bearing applications, the practical application of $\mathrm{Mg}$ based alloys faces the serious challenge of overcoming the rapid corrosion rates that occur within the physiological environment of the body. The types of biological corrosion occurring within the body environ ment and the influence of body fluid $\mathrm{pH}$, concentration of ions, protein adsorption on the implant surface and the influence of the surrounding tissues was discussed. To overcome the effects of biological corrosion, a nu mber of treatment methods designed to reduce the corrosion rate, such as the addition of alloying elements and surface modification techniques were discussed. The biological consequences of adding alloying elements to reduce the corrosion rate was explored and the need for careful selection was discussed. For example, alloying elements such as $\mathrm{Al}$ and $\mathrm{Li}$ can be used to improve the corrosion resistance of an alloy, but the release of their ions in the body can create undesirable health problems. Therefore, careful selection of the appropriate alloying elements and the resulting corrosion by-products were discussed in this article. Both these issues are critical for any material being considered for a biomedical application within the hu man body.

Furthermore, the development of new bioactive surface modifications and coatings, with superior physiochemical and mechanical properties has the potential to enhance the performance of $\mathrm{Mg}$ alloy implants by improving both their corrosion and wear resistance. The first type of surface modification discussed used conventional mechanical processes such as machining and rolling to enhance both surface and sub-surface properties. The second type of surface modification discussed examined the types of physical and chemical surface treatments that could deposit a metallic or ceramic coating or produce a surface conversion coating. The corrosion resistance and biocompatibility of the various surface modifications were discussed. In the case of ion implantation, the technique gave mixed corrosion resistance values when $\mathrm{Zn}$ was used to treat an $\mathrm{Mg}-\mathrm{Ca}$ alloy. While a conversion coating technique using a calcium phosphate compound produced a coating that not only reduced the corrosion rate, but also improved the biocompatibility and promoted bone formation at the surface of the Mg alloy. Whilst the use of polymeric coatings to protect implanted sensors and biomedical devices is well established, further studies are needed to examine the viability of using a polymeric material with suitable biodegradable properties to extend the operational life of a Mg alloy implant.

The combination of new $\mathrm{Mg}$ alloys and evolving surface 
modification processes, has presented the opportunity to design and develop a biocompatible material that has the potential to be used in an orthopaedic implant. The ability to select alloying elements and surface modifications provides the opportunity to design a specific $\mathrm{Mg}$ alloy implant with mechanical properties and biodegradation profile that can be tailored to the specific orthopaedic application. However, more biomedical studies are needed to investigate the interaction between the material surface and the surrounding tissue environment. Also, more in situ experimental studies are needed to examine the long-term effects of alloying elements released during the biological corrosion of $\mathrm{Mg}$ based alloys. The biomedical, materials science and engineering research presented in this review article has clearly demonstrated the potential of using $\mathrm{Mg}$ based alloys to manufacture orthopaedic implants, but there are still challenges to be overcome. The first challenge is to improve the corrosion resistance of $\mathrm{Mg}$ base alloys by using only biocompatible alloying elements and an appropriate biocompatible surface treatment that permits the controlled degradation of the implant. While the biomed ical challenge consists of more clinical trials to establish the long-term biocompatibility of $\mathrm{Mg}$ based alloys and their corrosion products within the body environment.

\section{ACKNOWLEDGEMENTS}

Dr Derek Fawcett would like to thank the Bill \& Melinda Gates Foundation for their research fellowship.

\section{REFERENCES}

[1] S.D. Gentry, C.A. Bramblett, The Anatomy and Biology of the Human Skeleton, Texas A\&M University Press 1988,p.4.

[2] G.A. Rodan, Bone homeostasis, The National Academy of Sciences, USA Vol. 95, (1998), p. 13361-13362.

[3] M.J. Olszta, X. Cheng, S.S. Jee, R. Kumar, Y.Y. Kim, M.J. Kaufman, E.P. Douglas, L.B. Gower, Bone structure and formation: A new perspective, Materials Science and Engineering, Vol. 58, (2007), p. 77-116.

[4] N. Shepard, Role of proteoglycans in calcification, in: E. Bonucci (Ed.), Calcification in Biological Systems, CRC Press, Boca Raton, (1992), p. 41

[5] E.P. Katz, E. Wachtel, M. Yamauichi, G.L. Mechanic, The structure of mineralized collagen fibrils, Connective Tissue Research, Vol. 21, No. 1-4, (1989), p. 149-158.

[6] W.J. Landis, M.J. Song, A. Leith, L. McEwen, B.F. McEwen, Mineral and organic matrix interaction in normally calcifying tendon visualized in 3 dimensions by high-voltage electron-microscopic tomography and graphic image-reconstruction, Journal of Structural Biology, Vol. 110, No.1, (1993), p. 39-54.

[7] B. Wopenka, J.D. Pasteris, A mineralogical perspective on the apatite in bone, Materials Science and Engineering C, Vol.
25, No. 2, (2005), p. 131-143.

[8] S. Weiner, H.D. Wagner, The Mineral Bone: StructureMechanical function relations, Annual Review of Materials Science Vol. 28, (1998), p. 271-298.

[9] C. Hellmich, F.J. Ulm, Average hy droxy apatite concentration is uniform in the extracollagenous ultrastructures of mineralized tissues: evidence at the 1-10 micron scale, Biomechanics and Modeling in Mechanobiology, Vol. 2, (2003), p. 21-36.

[10] C.F. Nawrot, D.J. Campbell, A Chromatographic Study of the Relative Affinities of Rat Bone and Skin Collagen 1 Chains for Hy droxy ap atite, Journal of Dental Research, Vol. 56, No. 8, (1977), p. 1017-1022.

[11] W.F. Neuman, M.W. Neuman, The chemical dynamics of bone mineral, Chicago, The University of Chicago Press, 1958.

[12] R.Z. LeGeros, Properties of osteoconductive biomaterials: calcium phosphates. Clinical Orthopaedics \& Related Research, Vol. 395, (2002), p. 81-98.

[13] R.A. Young, Some aspects of crystal structure modelling of biological apatites, In: Colloques Internationeaux C.N.S.R, Paris, No. 230, (1976), p. 21-40.

[14] E.P. Katz, S.T. Li, Structure and function of bone collagen fibrils, Journal of Molecular Biology, Vol. 80, No. 1, (1973), p. $1-15$.

[15] C.R.F. Azevedo, Failure analysis of a commercially pure titanium plate for osteosynthesis, Engineering Failure Analysis, Vol. 10, No. 2, (2003), p. 153-164.

[16] Y.C. Fung, Biomechanics: Mechanical properties of living tissue, $2^{\text {nd }}$ ed; Springer-Verlag: New York, USA, (1993), p. 225-229.

[17] J.C. Adams, D.L. Hamblen, Outline of Fractures, $10^{\text {th }} \mathrm{ed}$; Churchill Livingstone: London, UK, (1992), p. 3-18.

[18] K. Wang, The use of titanium for medical applications in the USA, Materials Science and Engineering: A, Vol. 213, No. 1-2, (1996), p. 134-137.

[19] M. Long, H.J. Rack. Titanium alloys in total joint replacement - A materials science perspective, Biomaterials, Vol. 19, No. 18, (1998), p. 1621-1639.

[20] A. Lambotte, L'utilisation du magnesium comme materiel perdu dans l'osteosynthèse, Bulletins et. Mémoires de la Societe Nationale de Chirurgie, Vol. 28, ( 1932), p.1325-1334.

[21] M. P. Staiger, A. M. Pietak, J. Huadmai, G. Dias, Magnesium and its alloys as orthopedic biomaterials: a review, Biomaterials, Vol. 27, No. 9, (2006), 1728-1734.

[22] R. Murugan, S. Ramakrishna, Development of nanocomposites for bone grafting, Composites Science and Technology, Vol. 65, No. 15-16, (2005), p. 2385-2406.

[23] A.M. Rasmir-raven, D.C. Richardson, H.M. Aberman, D.J. Deyong, The response of cancellous and cortical canine bone to hy droxy lap atite-coated and uncoated titanium rods, Journal of Applied Biomaterials, Vol.6, No.4, (1995), p. 237-242.

[24] J. Nagels, M. Stokdijk, P.M. Rozing, Stress shielding and bone resorportion in shoulder arthroplasty, Journal of 
Shoulder and Elbow Surgery, Vol. 12, No. 1, (2003), p. 35-39.

[25] C. Lhotka, T. Szekeres, I. Steffan, K. Zhuber, K. Zweymuller. Four-year study of cobalt and chromium blood levels in patients managed with two different metal-on-metal total hip replacements. Journal of Orthop edic Research, Vol. 21, No. 2, (2003), p. 189-195.

[26] P.A. Dearnly, A brief review of test methodologies for surface-engineered biomedical implant alloys, Surface and Coatings Technology, Vol. 198, No. 1-3, (2005), 483-490.

[27] D.R. Haynes, S.J. Boyle, S.D. Rogers, D.W. Howie, B. Vernon-Robert, Variation in cytokines induced by patients from different prosthetic materials, Clinical Orthopaedics and Related Research, Vol. 352, (1998), p. 323-230.

[28] N.L. Saris, E. Mervaala, H. Karppanen, J.A. Khawaja, A. Lewenstam, Magnesium. An up date on phy siological, clinical and analy tical aspects, Clinica chimica acta, Vol. 294, (2000), p. 1-26.

[29] S.R. Kim, J.H. Lee, Y.T. Kim, D.H. Riu, S.J. Jung, Y.J. Lee, S.C. Chung, Y.H. Kim, Synthesis of $\mathrm{Si}, \mathrm{Mg}$ substituted hydroxy ap atites and their sintering behaviours, Biomaterials Vol.24, No.8, (2003), p. 1389-1398.

[30] A. D. Robinson, R.W. Griffith, D. Shechtman, R.B. Evans, M.G. Conzemius, In vivo antibacterial properties of magnesium metal against Escherichia coli, Pseudomonas aeruginosa and Staphylococcus aureus, Acta Biomaterialia, Vol. 6, (2010), p. 1869-1877.

[31] P.E. DeGarmo, Materials and processes in manufacturing, $5^{\text {th }}$ ed. New York, Collin Macmillan, 1979

[32] M. Razavi, M.H. Fathi, M. Meratian et al. Microstructure, mechanical properties and biocorrosion evaluation of biodegradable AZ91-FA nanocomposites for biomedical applications, Materials Science and Engineering A, Vol. 527, No.26, (2010), p.6938-6944.

[33] A. Feng, Y. Han, The microstructure, mechanical and corrosion properties of calcium phosp hate reinforced ZK60A magnesium alloy composites, Journal of Alloys and Compounds, Vol. 504, (2010), p.585-593.

[34] L.C. Li, J.C. Gao, Y. Wang, Evaluation of cyto-toxicity and corrosion behaviour of alkali-heat-treated magnesium in simulated body fluid, Surface and Coatings Technology, Vol. 185, (2004), p. 92-98.

[35] P.S. Mark, M.P. Alexis, H. Jerawala, D. Goerge, Magnesium and its alloys as orthopaedic biomaterials: A review, Biomaterials, Vol. 27, No. 9, (2006), p.1728-1734.

[36] L. Yang, Z. Li-Ming, Chemical structural and chain conformational characterization of some bioactive polysaccharides isolated from natural sources, Carbohydrate polymers, Vol. 76, No.3, (2009), p.349-361.

[37] V.R. Sinha, K. Rachna, Polysaccharides in colon-specific drug delivery, International Journal of Pharmaceutics, Vol. 224, (2001), p. 19-38

[38] G. Crini, Recent developments in polysaccharide-based materials used as adsorbents in wastewater treatment, Progress in Polymer Science, Vol. 30, No. 1,(2005), p. 38-70.

[39] A. Kanazawa, M. Suzuki, Solid-state poly-condensation of natural aldopentoses and 6-deoxyaldohexoses. Facile preparation of highly branched poly saccharide, Polymer Vol. 47, No.1, (2006), p.176-183.

[40] S. Run Cang, J.M. Fang, A. Goodwin, J.M. Lawther, A.J. Bolton, Fractionation and characterization of poly saccharides from abaca fibre, Carbohydrate Polymers, Vol. 37, No.4, (1998), p.351-359.

[41] M.N.V. Ravi Kumar, A review of chitin and chitosan applications, Journal of Reactive and Functional Polymers, Vol.46, (2000), p.1-27.

[42] X. Wang, Y. Du, J. Luo, B. Lin, J.F. Kennedy, Chitosan/organic rectorite nanocomposite films: Structure, characteristic and drug delivery behavior, Carbohydrate Polymers, Vol. 69, (2007), p. 41-49.

[43] J.M. Dang, K.W. Leong, Natural polymers for gene delivery and tissue engineering, Advanced Drug Delivery Reviews, Vol. 58, (2006), p.487- 499.

[44] M.L. Lorenzo-Lamosa, C. Remunan-Lopez, J.L. Vila-Jato, M.J. Alonso, Design of microencapsulated chitosan microspheres for colonic drug delivery, Journal of Controlled Release, Vol. 52, (1998), p.109-118.

[45] M. George, T.E. Abraham, Polyionic hydrocolloids for the intestinal delivery of protein drugs: Alginate and chitosan a review, Journal of Controlled Release, Vol. 114, (2006), p.1-14.

[46] D. Thacharodi, K. Panduranga Rao, Development and in vitro evaluation of chitosan-based transdermal drug delivery systems for the controlled delivery of propranolol hydrochloride, Biomoterials, Vol.16, No.2, (1995), p.145-148.

[47] M. Halbleib, S. Thomas, L. Claudio de, D. von Heimburgc, H. Hauner, Tissue engineering of white adipose tissue using hyaluronic acid-based scaffolds. I: in vitro differentiation of human adipocyte precursor cells on scaffolds, Biomaterials, Vol. 24, (2003), p. 3125-3132.

[48] J. Jagur-Grodzinski, Biomedical application of functional polymers, Reactive \& Functional Polymers, Vol. 39, (1999), p. $99-138$.

[49] M. G. Cascone, B. Sim, S. Dowries, Blends of synthetic and natural polymers as drug delivery systems for growth hormone, Biomaterials, Vol.16, (1995), p.569-574.

[50] K. Kafedjiiski, R.K.R. Jetti, F. Florian, H. Hoyer, M. Werle, M. Hoffer, A. Bernkop-Schnurch, Synthesis and in vitro evaluation of thiolated hyaluronic acid for mucoadhesive drug delivery, Internation Journal of Pharmaceutics, Vol.343, No. 1-2, (2007), p.48-58.

[51] S. Jockenhoevel, G. Zund, S.P. Hoerstrup, K. Chalabi, J.S. Sachweh, L. Demircan, B.J. Messmer, M. Turina, Fibrin gel advantages of a new scaffold in cardiovascular tissue engineering, European Journal of Cardio-thoracic Surgery, Vol.19, (2001), p. 424-430.

[52] E. A. Ryan, L. F. Mockros, A. M. Stern, L. Lorand, Influence of a Natural and a Synthetic Inhibitor of Factor XIIIa on Fibrin Clot Rheology, Biophy sical Journal, Vol. 77, (1999), p. 2827-2836

[53] T.H. Chun, K.B. Hotary, F. Sabeh, A.R. Saltiel, E.D. Allen, S.J. Weiss, A Pericellular Collagenase Directs the 3-Dimensional Development of White Adipose Tissue, Cell, 
vol. 125, No.3, (2006), p.577-591.

[54] N.T. Dai, M.R. Williamson, N. Khammo, E.F. Adams, A.G.A. Coombes, Composite cell support membranes based on collagen and poly caprolactone for tissue engineering of skin, Biomaterials, Vol. 25, (2004), p. 4263-4271.

[55] T. Sato, G. Chen, T. Ushida, T. Ishii, N. Ochiai, T. Tateishi, J. Tanaka, Evaluation of PLLA-collagen hybrid sponge as a scaffold for cartilage tissue en gineering, Materials Science and En gineering C, Vol. 24, No. 3, (2004), p. 365-372.

[56] S. A garwal, J.H. Wendorff, A. Greiner, Progress in the Field of Electro-spinning for Tissue Engineering Applications, Advanced Materials, Vol. 21, No. 32-33, (2009), p. 3343-3351.

[57] Y. Dong, F. Si-Shen, Methoxy poly(ethylene glycol)-poly (lactide) (MPEG-PLA) nanoparticles for controlled delivery of anticancer drugs, Biomaterials, Vol. 25, (2004), p. 2843-2849.

[58] X. Zheng, B. Kan, M. Gou, S. Fu, J. Zhang, K. Men, L. Chen, F. Luo, Y. Zhao, X. Zhao, Y. Wei, Z. Qian, Preparation of MPEG-PLA nanoparticle for honokiol delivery in vitro, International Journal of Pharmaceutics, Vol. 386, No. 1-2, (2010), p. 262-267.

[59] J. Chen, B. Tian, X. Yin, Y. Zhang, D.Hu, Z. Hu, M. Liu, Y. Pan, J. Zhao, H. Li, C. Hou, J. Wang, Y. Zhang, Preparation, characterization and transfection efficiency of cationic PEGylated PLA nanoparticles as gene delivery systems, Journal of Biotechnology, Vol. 130, (2007), p. 107-113.

[60] H. Kranz, R. Bodmeier, Structure formation and characterization of inject able drug loaded biodegradable devices: In situ implants versus in situ micro-particles, European journal of pharmaceutical sciences, Vol.34, No. 2-3, (2008), p.164-172.

[61] J.M. Kanczler, P.J. Ginty, J.J.A. Barry, N.M.P. Clarke, S.M. Howdle, K.M. Shakesheff, R.O.C. Oreffo, The effect of mesenchymal populations and vascular endothelial growth factor delivered from biodegradable polymer scaffolds on bone formation, Biomaterials, Vol. 29, (2008), p.1892-1900.

[62] L. Rimondini, N. Nicoli-Aldini, M. Fini, G. Guzzardella, M. Tschon, R. Giardino, In vivo experimental study on bone regeneration in critical bone defects using an injectable biodegradable PLA/PGA copolymer, Oral Surgery, Oral Medicine, Oral Pathology, Oral Radiology, Endodontics, Vol. 99, No. 2, (2005), p.148-154.

[63] C. F. Chu, A. Lu, M. Liszkowski, R. Sipehia, Enhanced growth of animal and human endothelial cells on biodegradable polymers, Biochimica et Biophy sica Acta, Vol. 472, No. 3, (1999), p.479-485.

[64] L. Calandrelli, B. Immirzi, M. Malinconico, M. G. Volpe, A. Oliva, F. Della Ragione, Preparation and characterisation of composites based on biodegradable polymers for in vivo application, Polymer, Vol. 41, (2000), p. 8027-8033.

[65] Z. Wang, S. Wang, Y. Marois, R. Guidoin, Z. Zhang, Evaluation of biodegradable synthetic scaffold coated on arterial prostheses implanted in rat subcutaneous tissue, Biomaterials, Vol. 26, (2005), p.7387-7401.

[66] Z. Ma, C. Gao, Y. Gong, J. Shen, Cartilage tissue engineering PLLA scaffold with surface immobilized collagen and basic fibroblast growth factor. Biomaterials. Vol. 26, No. 11,
(2005), p. 1253-1259.

[67] A. Aubert-Pouessel, M.C. Venier-Julienne, A. Clavreul, M. Sergent, C. Jollivet, C.N. Montero-Menei, E. Garcion, D.C. Bibby, P. Menei, J.P. Benoit, In vitro study of GDNF release from biodegradable PLGA microspheres, Journal of Controlled Release, Vol. 95, No. 3, (2004), p. 463-475.

[68] M. Qiao, D. Chen, X. Ma, Y. Liu, Inject able biodegradable temperature-responsive PLGA-PEG-PLGA copolymers: Synthesis and effect of copolymer composition on the drug release from the copolymer-based hydrogels, International Journal of Pharmaceutics, Vol. 294, No. 1-2, (2005), p. 103-112.

[69] J.J. Lee, S.G. Lee, J.C. Park, Y.I. Yang, J.K. Kim, Investigation on biodegradable PLGA scaffold with various pore size structure for skin tissue engineering, Current Applied Physics, Vol. 7S1, (2007), p.e37-e40.

[70] H.S. Yoo, T.G. Park, Biodegradable polymeric micelles composed of doxorubicin conjugated PLGA-PEG block copolymer, Journal of controlled Release, Vol. 70, (2001), p. 63-70.

[71] M. Todo, S.D. Park, T. Takayama, K. Arakawa, Fracture micro-mechanisms of bio-absorbable PLLA/PCL polymer blends, Engineering Fracture Mechanics, Vol. 74, No. 12, (2007), p.1872-1883.

[72] F. Rezgui, M. Swistek, J. M. Hiver, C. G'Sell, T. Sadoun, Deformation and damage upon stretching of degradable polymers (PLA and PCL), Polymer, Vol. 46, No. 18, (2005), p.7370-7385.

[73] L. Calandrelli, B. Immirzi, M. Malinconico, M. G. Volpe, A. Oliva, F. D. Ragione, Preparation and characterization of composites based on biodegradable polymers for "in vivo" application, Polymer, Vol. 41, No. 22, (2000), p. 8027-8033.

[74] B. Li, J. Yu, J. Jung, M. Ree, Amidolysis of some biodegradable polymers, Polymer Degradation and Stability, Vol. 65, No.1, (1999), p.161-163.

[75] Y. Iwasaki, S. Sawada, K. Ishihara, G. Khang, H. B. Lee, Reduction of surface-induced inflammatory reaction on PLGA/MPC polymer blend, Biomaterials, Vol. 23, No. 18, (2002), p.3897-3903.

[76] Y. Li, J. Nothnagel, T. Kissel, Biodegradable brush-like graft polymers from poly(o,L-lactide) or poly(o,L-lactidecoglycolide) and charge-modified, hydrophilic dextrans as backbone-Synthesis, characterization and in vitro degradation properties, Polymer, Vol. 38, (1997), p. 6197-6206.

[77] Y.C. Wang, M.C. Lin, D.M. Wang, H.J. Hsieh, Fabrication of a novel porous PGA-chitosan hybrid matrix for tissue engineering, Biomaterials, Vol.24, (2003), p. 1047-1057.

[78] C.Y. Hsieh, S.P. Tsai, D.M. Wang, Y.N. Chang, H.J. Hsieh, Preparation of g-PGA/chitosan composite tissue engineering matrices, Biomaterials, Vol. 26, (2005), p. 5617-5623.

[79] K. Rezwan, Q.Z. Chen, J.J. Blaker, A.R. Boccaccini, Biodegradable and bioactive porous polymer/inorganic composite scaffolds for bone tissue engineering, Biomaterials, Vol. 27, (2006), p. 3413-3431.

[80] C.M. Agrawal, Reconstructing the Human Body Using Biomaterials, Journal of the Minerals, Metals and Materials Society, Vol. 50, No. 1, (1998), p. 31-35. 
[81] S. Ramakrishna, M. Ramalingam, T.S. Sampath, W.O Soboyejo, Biomaterials: A Nano Approach, CRC Press, Boca Raton, USA, Chap 7 (2010) p.188-196.

[82] L.L. Hench, J. Wilson, An introduction to bioceramics, World Scientific Publishing Co Pt Ltd: Singapore (1993) p.1-24.

[83] L.L. Hench, Bioceramics: From concept to clinic, Journal of the American Ceramic Society, Vol. 74, No.7, (1991), p. $1487-1510$.

[84] P.X. Ma, Biomimetric materials for tissue engineering, Advanced Drug Delivery Reviews, Vol. 60, No.2, (2008), p. 184-198.

[85] J.B. Park, J.D. Bronzino, Biomaterials principles and applications, CRC Press, Boca Raton, Florida, USA, 2003.

[86] I. Thompson, L.L Hench, Medical applications of composites: In comprehensive composite materials, Edited: A. Kelly, C. Zweben, Amsterdam Elsevier Science: 727 (2000).

[87] Ducheyne P, L.L. Hench, A. Kagan, M. Martens, A. Bursens, J.C. Mulier ,Effect of hydroxyapatite impregnation on skeleton bonding of porous coated implants, Biomedical Materials Research, Vol.14, No.3, (1980), p. 225-237.

[88] S. Itoh, M. Kikuchi, Y. Koyama, N.H. Matumoto, K. Takakuda, K. Shinomiya, J. Tanaka, Development of a novel biomaterial, hydroxyapatite/collagen composite for medical use, Biomedical Materials and En gineering, Vol. 15, No. 1-2, (2005), p.29-41.

[89] C.P. McCord, Chemical gas gangrene from metallic magnesium, Industrial Medicine, Vol. 11, (1942), 71-79.

[90] C.E. Wen, M. Mabuchi, Y. Yamada, K. Shimojima, Y. Chino, $\mathrm{T}$. Asahina, Processing of biocompatible porous $\mathrm{Ti}$ and $\mathrm{Mg}$. Scripta Materialia, Vol.45, No.10, (2001), p.1147-1153.

[91] D.Williams, Medical Device Technology, Vol. 17, No. 3, (2006), p. 9-10

[92] F. Witte, V. Kaese, H. Haferkamp, E. Switzer, A Meyer-Lindenberg, C.J. Wirth, H. Windhagen, In vivo corrosion of magnesium alloys and the associated bone response, Biomaterials, Vol. 26, No. 17, (2005), p.3557-3563.

[93] E. Ghali, Corrosion resistance of aluminium and magnesium alloys, understanding, performance and testing, Chap 10, Pub: John Wiley (2010), 349.

[94] B.A. Shaw, Corrosion resistance of magnesium alloy s. In: Ed: Stephens D. ASM handbook, Vol 13a: corrosion fundamentals, testing and protection. UK: ASM Int.; 2003.

[95] A.M. Fekry, M.A. Ameer, Electrochemistry and impedance studies on titanium and magnesium alloys in Ringer's solution, International Journal of Electrochemical Science, Vol.6, (2011), p.1342-1354.

[96] G. Song, Control of biodegradation of biocompatible magnesium alloys, Corrosion Science, Vol.49, No. 4, (2007), p.1696-1701.

[97] R.L. Williams, D.F. Williams, Albumin adsorption on metal surfaces, Biomaterials, Vol. 9, No.3, (1998), p.206-212.

[98] K. Endo, Chemical modifications of metallic implant surfaces with bio-functional proteins (Part 2).Corrosion resistance of a chemically modified NiTi alloy, Dental Materials Journals, Vol. 14, (1995), p.199-210.
[99] W.D. Muller, M.L. Nascimento, M. Zeddies, M. Corsico, L.M. Gassa, M.A. Fernandez, L. de Mele, Magnesium and its alloys as degradable biomaterials. Corrosion studies using potentiodynamic and EIS electrochemical techniques, Materials Research, Vol. 10, No.1, (2007), p. 5-10.

[100] R.M.E. Diamant, Applied Chemistry for Engineers, The Pitman Press, Bath, Great Britain, (1972), Chap 5, p. 86-105.

[101] J.J. Jacobs, J.L. Gilbert, R.M. Urban, Corrosion of metal orthopaedic implants, The Journal of Bone and Joint Surgery, American volume, Vol. 80, (1998), p. 268-82

[102] R. Zeng, E. Han, W. Ke, Corrosion of artificial aged magnesium alloy $\mathrm{AZ} 80$ in 3.5 wt pet $\mathrm{NaCl}$ solutions, Journal of Materials Science and Technology, Vol.23, No. 3, (2007), p. $353-358$

[103] OnlineAvailable:http://corrosionist.com/Pitting_Crevice_Co rrosion.htm.

[104]R. Ambat, N.N. Aung, W. Zhou, Evaluation of micro-structural effects on corrosion behaviour of AZ91D magnesium alloy, Corrosion Science,Vol. 42, (2000), p. $1433-1455$

[105] L.J. Liu, M. Schlesinger, Corrosion of magnesium and its alloys. Corrosion Science, Vol. 51, (2009), p. 1733-1737.

[106] R. Zeng, W. Dietzel, F. Witte, N. Hort, C.Blawert, Progress and challenge for magnesium alloys as biomaterials, Advanced Biomaterials, Vol. 35, (2008), p. B3- B14.

[107] M.G. Fontana, N.D. Greene, Corrosion engineering, McGraw-Hill, New York, (1987).

[108] OnlineAvailable: http://corrosion.ksc.nasa.gov/fretcor.htm.

[109] L. J. Korb, ASM handbook- ASM International, Corrosion, Vol. 13, (1987).

[110]A. Neyman, O. Olszewski, Research on fretting wear dependence of hardness ratio and friction coefficient of fretted couple, Wear of materials, International conference No. 9, San Francisco CA, USA, Wear, vol. 162-64, Part B, (1993), pp. 939-943.

[111] P. Shewmon, G. Sundararajan, The erosion of metals, Annual Review of Materials Science, Vol. 13, (1983), p. 301-318.

[112] P. A. Dearnley, Surface and Coating Technology, (2005), p. 198- 483.

[113] K.W. Miller, Material performance and evaluation, ed. R.H. Jones, ASM International, Ohio, (1993), p. 251.

[114] N. Winzer, A. Atrens, G. Song, E. Ghali, W. Dietzel, K.U. Kainer, N. Hort, C. Blawert, Advance Engin eering Materials, Vol. 7, (2005), p. 659-693.

[115] S.C. Dexter, Corrosion, Metals Handbook, edited by L. J. Korband, D. L. Olson, ASM International, Materials Park, OH,ASM International, USA, Vol. 13, No. 9, (1987), p. 123-135.

[116] T. Valente, Journal of Materials Science Letters, Vol. 20, (2001), p. 67-69.

[117] N. Winzer, A. Atrens, W. Dietzel, G. Song, K.U. Kainer, Stress corrosion cracking in magnesium alloys: characterisation and prevention, JOM, Vol. 59, No. 8, (2007), p. $49-53$. 
[118] N. Winzer, A. Atrens, G. Song, E. Ghali, W. Dietzel, K. Kainer, N. Hort, C. Blawert, A Critical Review of the Stress Corrosion Cracking (SCC) of Magnesium Alloys. Advanced Engineering Materials, Vol. 7, No. 8, (2005), p. 659-693.

[119] R.G. Song, C. Blawert, W. Dietzel, A. Atrens, A study of the stress corrosion cracking and hydrogen embrittlement of AZ31 magnesium alloy. Materials Science and Engineering A - Structural Materials Properties Microstructure And Processing, Vol 399, No. 1-2, (2005), p. 308-317.

[120] E. Ghali, W. Dietzel, K.U. Kainer. Journal of Materials Engineering and Performance, Vol. 13, No. 1, (2004), p. 7-25.

[121] G. Song, Recent Progress in Corrosion and Protection of Magnesium Alloys, Advanced Engineering Materials, Vol. 7, No. 7, (2005), p. 563-586.

[122] F. Witte, N. Hort, C. Vogt, S. Cohen, K.U. Kainer, R. Willumeit, F. Fey erabend, Degradable biomaterials based on magnesium corrosion, Current Opinion in Solid State and Materials Science, Vol. 12, (2008), p. 63-72.

[123] S. Song, G.L. Song, W. Shen and M.Liu. Corrosion and electrochemical evaluation of coated magnesium alloys. Corrosion. Vol. 68, No. 1, (2012), p. 015005-1-015005-12.

[124] G.L. Song, A. Andrej, Corrosion mechanisms of magnesium alloys, Advanced Engineering Materials, Vol. 1, (1999), p. 11-33.

[125] F. Zucchi, V. Grassi, A. Frignani, C. Monticelli, G. Trabanelli, Electrochemical behaviour of a magnesium alloy containing rare earth elements, Journal of Applied Electrochemistry, Vol. 36, (2006), p. 195-204.

[126] Z. Li, X. Gu, S. Lou, Y. Zheng. The development of binary $\mathrm{Mg}-\mathrm{Ca}$ alloys for use as biodegradable materials within bone, Biomaterials, Vol. 29, (2008), p. 1329-1344.

[127]F. Witte, H.A. Crostack, J. Nellesen, F. Beckmann, Characterisation of degradable magnesium alloys as orthopaedic implant materials,synchrotron-radiation-based microtomo graphy, (2001).

[128] F. Witte, H. Ulrich, M. Rudert, E. Willbold, Biodegradable magnesium scaffolds: Part 1: Appropriate inflammatory response, Journal of Biomaterials Research, Vol. 81A, No. 3, (2007), p. 748-756.

[129] F. Witte, H. Ulrich, C. Palm, E. Willbold, Biodegradable magnesium scaffolds: Part II: Peri-implant bone remodeling, Journal of Biomaterials Research, Vol. 81A, No. 3, (2007), p. $757-765$.

[130] S.V. Verstraeten, L. Aimo, P.I. Oteiza, Aluminium and lead: molecular mechanisms of brain toxicity, Archives of Toxicolgy, Vol. 82, (2008), p. 789-802.

[131] S.S.A. El-Rahman, Neuropathology of aluminium toxicity in rats: glutamate and GABA impairment, Pharmacological Research, Vol. 47, (2003), p. 189-194.

[132] N. Yumiko, T. Yukari, T. Yasuhide, S. Tadashi, I. Yoshio, Differences in behaviour among the chlorides of seven rare earth elements administered intravenously to rats, Fundamental and Applied Toxicology, Vol. 37, (1997), p. 106-116.

[133] Report of Environmental Health Impacts from Exposure to Metals, Simla, India, WHO, (2005).
U.[134] Z. Li, X. Gu, S. Lou, Y. Zheng, The development of binary $\mathrm{Mg}-\mathrm{Ca}$ alloys for use as biodegradable materials within bone, Biomaterials, Vol. 29, (2008), p. 1329-1344.

[135] X. Gu, Y. Zheng, Y. Cheng, S. Zhong, T. Xi, In vitro corrosion and biocompatibility of binary magnesium alloys, Biomaterials, Vol. 30, (2009), p. 484-498.

[136] T.P. Rucdi, W.M. Murphy, AO Principle of Fracture Management, AO Publishing, Dübendorf, Switzerland, (2002), p. 13-14.

[137] G.B. Wei, P.X. Ma, Structures and properties of nano-hydroxy apatite/polymer composite scaffolds for bone tissue engineering, Biomaterials, Vol. 25,(2004), p. $4749-4757$

[138] D.M. Brunette, J. Ratkay, B. Chehroudi, The bone-biomaterial interface, Toronto: University of Toronto Press, (1991), p. 49-61.

[139] B. Boyan, T. Hummert, K. Kieswetter, D. Schraub, D. Dean, Z. Schwartz, Effect of Titanium surface characteristics on chondrocytes and osteoblasts in vitro, Cells Materials, Vol. 5, No. 4, (1995), p. 323-335.

[140] M. Jayaraman, U. Meyer, M. Buhner, U. Joos, H.P. Wiesmann, Influence of titanium surfaces on attachment of osteoblast-like cells in vitro, Biomaterials, Vol. 25, No. 4, (2004), p. 625-631.

[141]D. Crotty, C. Stinecker, B. Durkin, Plating Difficult Substrates with Electroless Nickel, Products Finishing, Vol. 60, (1996), p. 44.

[142] J.E. Gray, B. Luan, Protective coatings on magn esium and its alloys - a critical review, Journal of Alloys and Compounds, Vol. 336, No. 1, (2002), p. 88-113.

[143] B. Denkena, D. Boehnke, L. de León, Machining induced residual stress in structural aluminium parts. Production Engineering, Vol. 2, No. 3, (2008), p. 247-253.

[144] M. Salahshoor, Y.B. Guo, Cutting mechanics in high speed dry machining of biomedical magnesium-calcium alloy using internal state variable plasticity model. International Journal of Machine Tools and Manufacture, Vol. 51, (2011), p. 579-590.

[145] B. Denkena, A. Lucas, Biocompatible magnesium alloys as absorbable implant materials-Adjusted surface and subsurface properties by machining processes. Annals of the CIRP, Vol. 56, No. 1, (2007), p. 113-118.

[146] B. Denkena, A. Lucas, F. Thorey, H. Waizy, N. Angrisani, A. Meyer-Lindenberg, Biocompatible magnesium alloys as degradable implant materials-Machining induced surface and subsurface properties and implant performance, Special Issues on Magnesium Alloys, (2011), p. 109-128.

[147] E. Brinksmeier, M. Garbrecht, D. Meyer, J. Dong, Surface hardening by strain induced martensitic transformation, Production Engin eering, Vol. 2, No. 2, (2007), p. 109-116.

[148] N.V.D. Hoh, D. Bormann, A. Lucas, B. Denkena, C. Hackenbroich, A. Meyer-Lindenberg, Influence of different surface machin in gtreatments of magnesium-based resorbable implants on the degradation behaviour in rabbits. Advanced Engineering Materials, Vol. 11, No. 5, (2009), p. B47-B54.

[149] G. Reiner, M. Griepentrog, Hard coatings on magnesium 
alloys by sputter deposition using a pulsed d.c. bias voltage, Surface and Coatings Technology, Vol. 76-77, No. 2, (1995), p. $809-814$

[150] J. Senf, E. Broszeit, Wear and Corrosion Protection of Aluminum and Magnesium Alloys Using Chromium and Chromium Nitride PVD Coatings, Advance Engineering Materials, Vol. 1, No.2, (1999), p. 133-137

[151] S.B. Dodd, S. Morris, R.W. Gardiner, R.M.D. Brydson, S. Diplas, P. Tsakiropoulos, Priliminary corrosion evaluation of some novel bulk electron beam evaporated magnesium alloys, Corrosion Reviews. Vol. 16, No. 1-2, (1998), p. 159174.

[152] T. Mitchell, P. Tsakiropoulos, Microstructure property studies of in situ mechanically worked PVD Mg-Ti alloys, Magnesium Technology 2000, The Minerals, Metals and Materials Society, (2000), p. 169-174.

[153] S. Diplas, P. Tsakiropoulos, R.M.D. Brydson, Journal of Material Science and Technology, Vol. 15, (1999), p. 1349.

[154]R. Jethanandani, The development and application of diamond-like carbon films, JOM, (1997), p. 63-65.

[155] C.L. Liu, Y.C. Xin, X.B. Tian, J. Zhao, P.K. Chu, Corrosion resistance of titanium ion implanted AZ91 magn esium alloy, Journal of Vaccum Science and Technology A, Vol. 25, (2007), p. 334-339.

[156] H.E. Fang, W. Y. Zao, S. Zhou, Y. Huang, Y.L. Wang, Zn ion implantation and corrosion behaviour of new medical $\mathrm{Mg}$-Ca alloys. Metal Science and Heat treatment, Vol. 134, No. 14, (2009), p. 32-37.

[157] Y.Z. Wan, G.Y. Xiong, H.L. Luo, F. He, Y. Huang, Y.L. Wang, Influence of zinc ion implantation on surface nanomechanical performance and corrosion resistance of biomedical magnesium-calcium, Applied Surface Science, Vol. 254, (2008), p. 5514-5516.

[158] E.L. Zhang, L.P. Xu, K. Yang, Formation by ion plating of Ti-coating on pure $\mathrm{Mg}$ for biomedical applications, Scripta Materialia, Vol. 53, (2005), p. 523-527.

[159] R.H. Unger, Thermal spray coating, in ASM Handbook: Corrosion, Vol. 13, (1987), p. 458-460.

[160] J. Zhang, Y. Wang, R.C. Zeng, W.J. Huang, Effects of post heat treatment on the interfacial characteristics of aluminium coated AZ91D magnesium alloy, Materials Science Forum, Vol. 529, (2007), p. 546-549.

[161] X. Liu, P.K. Chu, C. Ding, Surface modification of titanium, titanium alloys, and related materials for biomedical applications. Materials Science and Engineering: R, Vol. 47, (2004), p. 49-121.

[162] R.C. Zeng, W. Dietzel, J. Chen, W.J. Huang, J. Wang Corrosion behavior of $\mathrm{TiO}_{2}$ coating on magnesium alloy AM60 in Hank's solution, Key Engineering Materials, Vol. 373/374, (2008), p. 289-295.

[163] R.C. Zeng, W. Dietzel, F. Witte, N. Hort, C. Blawert, Progress and challenges for magnes ium alloys as biomaterials. Advanced Engineering Materials, Vol. 10, (2008), p. B3-B14.

[164] D. Dube, M. Fiset, A. Couture, I. Nakatsugawa, Characterization and performance of laser melted AZ91D and AM60B, Materials Science and En gineering A, Vol. 299,
No. 1, (2001), p. 38-45.

[165] R. Galun, A. Weisheit, B.L. Mordike, I. Manna, Improving the surface properties of magnesium by laser alloying, Corrosion Reviews, Vo. 16, No. 1-2, (1998), p. 53-73.

[166] H. Hiraga, T. Inoue, Y. Kojima, S. Kamado, S. Watanabe, Surface modification by dispersion of hard particles on magnesium alloy with laser, Materials Science Forum, Vol. 253, (2000), p. 350-351.

[167] L.A. Dobrzañski, J. Domaga, T. Tañski, A. Klimpel, D. Janicki, Laser surface treatment of cast magnesium alloys, Materials Science and En gineering, Vol. 35, No. 2, (2009), p. 101-106.

[168] S. Hao, B. Gao, A. Wu, J. Zou, Y. Qin, C. Dong, J. An, Q. Guan, Surface modification of steels and magnesium alloy by high current pulsed electron beam, Nuclear Instruments and Methods in Physics Research Section B: Beam Interactions with Materials and Atoms, Vol. 240, No. 3, (2005), p. 646-652.

[169] V. Neubert, A. Bakkar, C.A. Huang, Magnesium alloys and their applications, $7^{\text {th }}$ International Conference, Wiley-VCH, Weinheim, (2006), p. 842.

[170] J. Yang, F. Cui, I.S. Lee, Surface modifications of magnesium alloys for biomedical applications, Annals of Biomedical Engineering, Vol. 39, No. 7, (2011), p. 1857- 1871.

[171] L.P. Xu, G.N. Yu, E. L. Zhang, F. Pan, K Yang, In vivo corrosion behaviour of $\mathrm{Mg}-\mathrm{Mn}-\mathrm{Zn}$ alloy for bone implant application. Journal of Biomedical Materials Research Part A, Vol. 83, No. 3, (2007), p. 703-711.

[172] E.H. Han, W.Q. Zhou, D.Y. Shan, W. Ke, Corrosion and. Protection of magnesium alloy AZ31D by a new conversion coating, Materials Science Forum, Vol. 419, No.4, (2003), p. 879-883.

[173] M.A. Gonzalez-Nunez, C.A. Nunez-Lopez, P. Skeldon, G.E. Thompson, H. Karimzadeh, P. Lyon, T.E. Wilks, A non-chromate conversion coating for magnesium alloys and magnesium-based metal matrix composites, Corrosion Science, Vol. 37, No. 11, (1995), p. 1763-1772.

[174] R.C. Zeng. J. Chen. W. Dietzel. N. Hort. K.U. Kainer. Electrochemical behavior of magnesium alloys in simulated body fluids, Transactions of Nonferrous Metals Society China, Vol. 17, (2007), p. s166-s170.

[175] T. Hassel. F.W. Bach. C. Krause. P. Wilk. Corrosion protection and re-passivation after the deformation of magnesium alloys coated with a protective magnesium fluoride layer, Magnesium Technology, 2005 edited by TMS (The Minerals, Metals and Materials Society), (2005), p. 485-490.

[176] F. Witte, J. Fischer, J. Nellesen, C. Vogt, J. Vogt, T. Donath, F. Beckmann, In vivo corrosion and corrosion protection of magnesium alloy LAE442, Acta Biomaterialia, Vol. 6, (2010), p. 1792-1799.

[177] J.C. Gao, Y. Xue, L.Y. Qiao, Y. Wang, Y. Zhang, Surface modification of magnesium with rare earth conversion films for biomedical protection, Materials Science Forum, Vol. 546/549, (2007), p. 601-604.

[178] F. Witte, F. Feyerabend, P. Maier, J. Fischer, M. Stormer, C. Blawert, W. Dietzel, N. Hort, Biodegradable magnesium- 
hydroxyapatite metal matrix composites, Biomaterials, vol. 28 , no. 13 , (2007), p. 2163-2174.

[179] D.W. Hutmacher, J.T. Schantz, C.X.F. Lam, K.C. Tan, T.C Lim, State of the art and future directions of scaffold-based bone en gin eering from a biomaterials perspective, Journal of Tissue Engineering and Regenerative Medicine, Vol. 1, (2007), p. 245-260.

[180] W.J.E.M. Habraken, J.G.C. Wolke, J.A. Jansen, Ceramic composites as matrices and scaffolds for drug delivery in tissue engin eering, Advanced Drug Delivery Reviews, Vol. 59, (2007), p. 234-248.

[181] A. Blom, Which scaffold for which application?, Current Orthopaedics, Vol. 21, No. 4, (2007), p. 280-287.

[182] P. Habibovic, K. De Groot, Osteoinductive biomaterials-properties and relevance in bone repair, Journal of Tissue Engineering and Regenerative Medicine, Vol.1, (2007), p. 25-32.

[183] S. Hiromoto, T. Shishido, A. Yamamoto, N. Maruyama, H. Somekawa, T. Mukai, Precipitation control of calcium phosphate on pure magnesium by anodization, Corrosion Science, Vol. 50, (2008), p. 2906-2913.

[184] S.J. Kalita, A. Bhardwaj, H.A. Bhatt, Nanocry stalline calcium phosphate ceramics in biomedical engineering, Materials Science and Engineering:C, Vol. 27, No. 3, (2007), p. 441-449.

[185] D.A. Cortes, H.Y. Lopez, D. Mantovani, Spontaneous and biomimetic apatite formation on pure magnesium, Materials Science Forum, (2007), p. 589-594.

[186] Y. Zhang, G. Zhang, M. Wei, Controlling the biodegradation rate of magnesium using biomimetic apatite coating, Journal of Biomedical Materials Research Part B, Vol. 89, (2008), p. 408-414.

[187] Y. Song, S. Zhang, J. Li, C.Zhao, X. Zhang, Electrodeposition of $\mathrm{Ca}-\mathrm{P}$ coatings on biodegradable $\mathrm{Mg}$ alloy: In vitro biomineralization behaviour, Acta Biomaterialia, Vol. 6, (2010), p. 1736-1742.

[188] C. Zhang, R.C. Zeng, R.S. Chen, C.L. Liu, J.C. Gao, Preparation of calcium phosphate coatings on Mg-1.0Ca alloy, Transactions of Nonferrous Metals Society of China, Vol. 20, (2010), p. s655-s659.

[189] M. Tomozawa, S. Hiromoto, Growth mechanism of hydroxyapatite coatings formed on pure magnesium and corrosion behavior of the coated magnesium, Applied Surface Science, Vol. 257, No.19, (2011), p. 8253-8257.

[190] S. Hiromoto, A. Yamamoto, High corrosion resistance of magnesium coated with hydroxy apatite directly synthesized in an aqueous solution, Electrochimica Acta, Vol. 54, (2009), p. 7085-7093.

[191] C. Wen, S. Guan, L. Peng, C. Ren, X. Wang, Z. Hu, Characterization and degradation behaviour of AZ31 alloy surface modified by bone-like hydroxyapatite for implant applications, Applied Surface Science, Vol. 255, (2009), p. 6433-6438.

[192] L. Xu, E. Zhang, K. Yang, Phosphating treatment and corrosion properties of $\mathrm{Mg}-\mathrm{Mn}-\mathrm{Zn}$ alloy for biomedical application, Journal of Materials Science: Materials in Medicine, Vol. 20, (2009), p. 859-867.
[193]L. Xu. F. Pan. G. Yu. L. Yang. E. Zhang. K. Yang. In vitro and in vivo evaluation of the surface bioactivitv of a calcium phos- phate coated magnesium alloy, Biomaterials, Vol. 30, (2009), p. 1512-1523.

[194] Y. Wang, M. Wei, J. Gao, Improve corrosion resistance of mannesium in simulated body fluid by dicalcium phosphate dihydrate coating, Materials Science and Engineering: C, Vol. 29, (2009), p. 1311-1316.

[195] A. Yanovska, V. Kuznetsov, A. Stanislavov, S. Danilchenko, L. Sukhodub, Calcium phosphate coatings obtained biomimetically on magnesium substrates under low magnetic fields, Applied Surface Science, (2010), doi:10.1016 / j.apsusc.2012.05.052.

[196] R.G. Guan, I. Johnson, T. Cui, T. Zhao, Z.Y. Zhao, X. Li, H. Liu. Electro-deposition of hydroxyapatite coating on $\mathrm{Mg}-4.0 \mathrm{Zn}-1.0 \mathrm{Ca}-0.6 \mathrm{Zr}$ alloy and in vitro evaluation degradation, hemolysis and cytotoxicity. Journal of Biomedical Materials Research - Part A, Vol. 100A, No. 4, (2012), p. 999-1015.

[197] L. Li, J. Gao, Y. Wang, Evaluation of cyto-toxicity and corrosion behaviour of alkali-heat-treated magnesium in simulated body fluid, Surface and Coating Technology, Vol. 185, (2004), p. 92-98.

[198] C.L. Liu, Y.C. Xin, G.Y. Tang, P.K. Chua, Influence of heat treatment on degradation behaviour of biodegradable cast AZ63 magnesium alloy in simulated body fluid, Materials Science and Engineering: A, Vol. 456, (2007), p. 350-357.

[199] Y. Mizutani, S.J. Kim, R. Ichino, M. Okido, Anodizing of Mg alloys in alkaline solutions, Surface and Coatings Technology, Vol. 169/170, (2003), p. 143-146.

[200] S. Hiromoto, T. Shishido, A. Yamamoto, N. Maruyama, H. Somekawa, T. Mukai, Precipitation control of calcium phosphate on pure magnesium by anodization, Corrosion Science, Vol. 50, (2008), p. 2906-2913.

[201] H. Kuwahara, Y. Al-Abdullat, N. Mazaki, S. Tsutsumi, T. Aizawa, Precipitation of magnesium apatite on pure magnesium surface during immersing in Hanks' solution, Materials Transaction, Vol. 42, No. 7, (2001), p. 1317-1321.

[202] J.L. Patel, N. Saka, Microplasmic ceramic coating, Interceram, Vol. 50, No. 5, (2001), p. 398-401.

[203] X.P. Zhang, Z.P. Zhao, F.M. Wu, Y.L. Wang, J.Wu, Corrosion and wear resistance of AZ91D magnesium alloy with and without microarc oxidation coating in Hanks' solution. Journal of Materials Science, Vol. 42, No. 20, (2007), p. 8523-8528.

[204] H. Hornberger, S. Virtanen, A.R. Boccaccini, Biomedical coatings on magnesium alloys $-\mathrm{A}$ review. Acta Biomaterialia, Vol. 8. No. 7, (2012), p. 2442-2455.

[205] G. Song, Control of biodegradation of biocompatible magnesium alloy, Corrosion Science, Vol. 49, No. 4, (2007), p. 1696-1701.

[206] G. Song, S. Song, A possible biodegradable magnesium implant material, Advanced Engineering Materials, Vol. 9, No.4, (2007), p.298-302.

[207] L. Wolgemuth, Assessing the performance and suitability of parylene coatings. Medical device and diagnostic industry, Vol.22, No.8, (2000), p. 42. 
[208] J. Jagur-Grodzinski, Polymers for tissue engineer ing, medical devices, and regenerative medicine.Con cise general review of recent studies, Polymers for Advanced Technologies, Vol. 17, No. 6, (2006), p. 395-418.

[209] W. Leventon, New coatings and processes add value to medical devices, Medical device and diagnostic industry, Vol. 23, No. 8, (2001), p. 48.

[210] J.J. Huang, Y.B. Ren, B.C. Zhang, K. Yang, Preparation and property of coating degradable $\mathrm{Mg}$ implant, Chinese Journal of Nonferrous Metals, Vol. 17, (2007), p.1465-1469.

[211] M.T.F. Reitman, J. McPeak, Protective coatings for implantable medical devices. Proceedings: Society of Plastic Engineers. ANTEC. (2005), p. 3120-3124.

[212] X.H. Xu, J. Cheng, C.H. Zhang, X.L. Yan, T.B. Zhu, K.D. Yao, L. Cao, Y. Liu, Bio-corrosion and polymer coating modification of magnesium alloys for medicine, Rare Metals Materials and Engineering, Vol. 37, (2008), p. 1225-1228.

[213] X.N. Gu, Y.F. Zheng, A review on magnesium alloys as biodegradable materials, Frontiers of Materials Science in China, Vol. 4, No.2, (2010), p. 111-115.

[214] L. Xu, E. Zhang, D. Yin, S. Zeng, K. Yang, In vitro corrosion behaviour of $\mathrm{Mg}$ alloys in a phosphate buffered solution for bone implant application, Journal of Materials Science: Materials in Medicine, Vol. 19, No.3, (2008), p. 1017-1025.

[215] H.S. Brar, M.O. Platt, M. Sarntinoranont, P. Martin, M.V. Manual, Magnesium as a biodegradable and bioabsorbable material for medical implants, Journal of the Minerals, Metals and Materials Society, Vol. 61, No. 9, (2009), p. 31-34.

[216] R.S. Busk, Magnesium products design: Marcel Dekker, New York, USA, (1987), p. 554.

[217] I.J. Polmear: Magnesium alloys and applications. Materials Science and Technology, Vol. 10, No.1, (1994), p. 1-16.

[218] O n lin eA vailable: http://www.carbones.at/eng/Products/ Magnesium-Mg-Alloy s-and-Mg-Granules
[219] P. Auerkari, Mechanical and physical propertries of engineering alumina ceramics. VTT Tiedotteita Meddelanden-Res earch Notes 1792. www.vtt.fi/inf/pdf/ tiedottect/1996/T1792.pdf

[220] M.P.E. Wenger, L. Bozec, M.A. Horton, P. Mesquida, Mechanical properties of collagen fibrils, Biophysical Journal, Vol. 93, (2007), p. 1255-1263.

[221] J. Black, Hastings GW, Handbook of biomaterials properties. Chapman \& Hall. London, Great Britain, (1998).

[222] W.A. Banks, A.J. Kastin, Aluminium-induced neurotoxicity: alterations in membrane function at the blood-brain barrier. Neuroscience Biobehavior Review. Vol. 13, (1989), p. 47-45.

[223] V. Rondeau, H. Jacqmin-Gadda, D. Commen ges, C. Helmer, J.F. Dartigues. Aluminium and silica in drinking water and the risk of Alzheimer's disease or cognitive decline: Findings from 15 year follow-up of the PAQUID cohort. American Journal of Epidemiology. Vol. 169, (2008), p. 489-496.

[224] D. Strausak, J.F. Mercer, H.H. Dieter, W. Stremmel, G. Multhaup, Copper in disorders with neurological symptoms: Alzheimers's, Menkes and Wilson disease. Brain Research Bulletin. Vol. 55, (2001), p. 175-178.

[225] G.L. Makar, J. Kruger, Corrosion of magnesium Int. Mater. Rev. Vol. 38, No. 3, (1993), p. 138-145

[226] V.C. Culotta, M. Yang and M. Hall. Manganese transport and trafficking: Lessons learned from Sac charomy ces cerecvisiae. Eukaryotic Cell, Vol. 4, (2005), p. 1159-1165.

[227] D. Persaud-Sharma, A. McGordon, Biodegradable magnesium alloys: A review of material development and applications. J. Biomim. Biomater. Tissue Eng. Vol. 12, (2012), p. 25-39.

[228] B. Zberg, P. Uggowitzer, J. Loffler, MgZnCa glasses without clinically observable hydrogen evolution for biodegradable implants. Nature Materials-Letters, Vol. 8, (2009), p. 887-891. 